\title{
A "Bilingual" Approach to Language \\ Rights: How Dialogue Between U.S. and International Human Rights Law May Improve the Language Rights Framework
}

Denise Gilman ${ }^{1}$

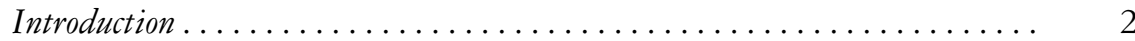

I. The U.S. and International Human Rights Approaches to

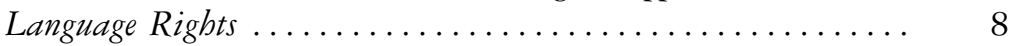

A. The U.S. Approach to Language Rights ............. 8

B. The International Human Rights Approach to Language Rights............................ 11

II. Improvements to be Made Through a "Bilingual" Approach to

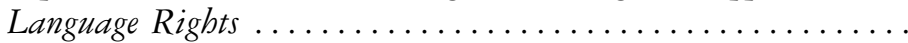

A. Improvements in the U.S. System Through Incorporation of the International Human Rights Law Approach .......... 18

1. Limitations of the Non-Discrimination Framework .... 19

2. Improvements to the Non-Discrimination Framework... 22

3. Improvements Beyond the Non-Discrimination

Framework - Recognizing the Value of Minority

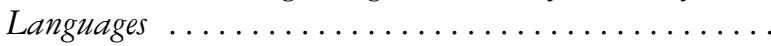

4. The Consequences of Incorporating the International

Human Rights Approach ................... 34

B. Improvements in the International Human Rights System

Through Incorporation of U.S. Legal System Conceptions ...

1. Limitations of the Cultural Approach ..............

2. Improvements to the Non-Discrimination Analysis Under International Human Rights Law............. 45

3. Improvements in the Treatment of Immigrants as Minority Language Speakers ................. 53

4. The Consequences of Incorporating the U.S. Non-

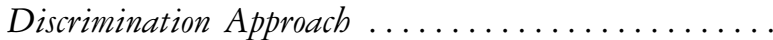

1. Clinical Professor of Law, University of Texas School of Law. J.D., Columbia Law School; B.A., Northwestern University. I am grateful to Mitch Berman, Michael Churgin, Ariel Dulitzky, Karen Engle, Barbara Hines, Deena Hurwitz, Deborah Palmer, and Cristina Rodríguez for their extremely helpful comments on drafts of this Article. 
III. Initial Proposal for the Development of a Doctrinal Framework

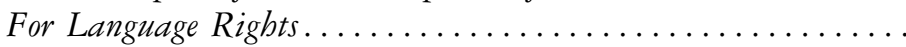

A. Identification of the Most Salient Factors Impacting

Recognition of Specific Language Rights ...............

B. A Proposed Doctrinal Framework Based on the Most Salient

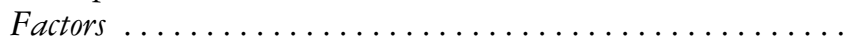

1. Language Rights in the Private Sphere............

2. Language Rights in the Quasi-Public Sphere .........

3. Language Rights in the Public Governmental Sphere...

Conclusion

\section{INTRODUCTION}

This Article was born out of a question posed to me by my eight-year-old son, Leo, who has been raised as a bilingual speaker of Spanish and English. Leo's question arose in response to a proposal to eliminate the brief weekly Spanish lesson provided to the children at his public elementary school in Austin, Texas. In an indignant tone, Leo asked, "Why don't they want us to learn Spanish when we have Mexico so nearby, and everybody there speaks Spanish?"

I was not a stranger to language rights issues when Leo posed the question. During previous years in Washington, D.C., I was deeply involved with a coalition of advocates that achieved adoption of a Language Access Act requiring D.C. government agencies to provide interpretation and translation services to non-English speakers who could not otherwise access their services or programs. ${ }^{2}$ I also represented individuals who suffered discrimination based on language, such as a Salvadoran man who successfully sued a Sheraton Hotel restaurant in the D.C. area after he was laid off and denied rehire because of his lack of English fluency, even though he had worked without difficulty as a dishwasher in the restaurant for fifteen years. ${ }^{3}$

However, Leo's question revealed a new dimension in language rights that I had not previously considered in any depth. Most of my work - in fact, most language rights work in the United States - has revolved around the extent to which individuals not fluent in English should be protected and assisted as they seek to ensure treatment on par with English speakers. Leo's concern was focused in a different direction. He did not understand why a more positive cultural value was not ascribed to a language other than English despite the obvious influence of Spanish in Texas and the importance of cross-cultural communications with Spanish speakers in Texas and across the border.

2. D.C. CODE $\$ \S 2-1932$ to 2-1933 (2001).

3. See EEOC Litigation Settlement Report - October 2005, EEOC, http://archive.eeoc.gov/litigation/ settlements/settlement10-05.html (last modified Feb. 2, 2006). 
Leo's question also seemed to reflect self-doubt about the place of his Spanish ability in school and in society. That doubt presumably resulted from the change in attitude that he experienced in school when our family moved from Washington, D.C. to Austin, Texas. In Washington, D.C., Leo attended a public bilingual immersion school where mastery of Spanish was fostered and celebrated. In Leo's Texas public school, in contrast, some saw Spanish class as entailing an unnecessary use of learning time, an unjustifiable expense, or worse.

My conversation with my son laid bare for me in a new way the breadth of issues encompassed in questions of language rights. It led me to consider a fuller range of claims to language rights, ${ }^{4}$ which span from communicating in a language that one understands to development and use of a minority language in spaces dominated by another language. I had viewed language rights through the limited lens of the U.S. legal system, which seeks to prevent discrimination against those unable to speak English. Leo's query honed in on the importance of languages other than English to culture and identity, which is a rights concern rarely glimpsed in the U.S. legal system but one of central importance in international human rights law.

In considering the treatment given to the range of language rights claims, two realities become apparent. First, no coherent legal framework for addressing language rights exists at either the domestic level in the United States or at the level of international human rights law. Second, when an effort is made to identify the underlying currents in the domestic U.S. legal system and in international human rights frameworks, two very distinct approaches to language rights emerge. These differences provide the opportunity for meaningful exchange to improve the treatment of language rights.

The laws, regulations, case law, and policies regarding language use in the United States form at best a patchwork and certainly have not woven themselves into a single scheme for viewing claims to language rights. ${ }^{5}$ International human rights treaties and interpretations by international tribunals have also failed to provide coherent analyses of claims of right in the language arena. ${ }^{6}$

4. This Article refers to language rights "claims" as a means of describing all assertions that a language right does or should exist. The reference is not limited to claims brought in litigation before a tribunal or even to demands for enforcement more generally. Instead, it covers all assertions or claims of right at both the normative and enforcement levels.

5. See Sandra Del Valle, Language Rights and the Law in the United States 4 (2003) (asserting that in the treatment of language rights in the United States, there are "few common principles uniting the judicial reasoning and there is an ad hoc nature to many decisions"); Bill Piatt, Toward Domestic Recognition of a Human Right to Language, 23 Hous. L. Rev. 885, 885 (1986) ("It is as though the threads [of language rights law] have not been woven into the fabric of the law, but rather surface as bothersome loose ends to be plucked when convenient.").

6. See Fernand de Varennes, Language, Minorities and Human Rights 70-71 (1996); Lauri Mälksoo, Language Rights in International Law: Why the Phoenix is Still in the Ashes, 12 Fla. J. INT'L L. 
Nor have legal or political theory scholars brought greater order to language rights. ${ }^{7}$ Much of the study of language rights by legal academics focuses on the use of language in specific contexts, such as the worksite or education. ${ }^{8}$ This lack of consideration given across the multiple contexts in which language issues may arise is not altogether surprising given the dizzying array of possibilities. The contexts include: education, government services (such as public housing, welfare benefits, police patrols, and disaster planning), jury service, civil and criminal legal proceedings, voting, participation in politics and campaigns, the adoption and publication of legislation, regulations and policies, employment, healthcare, public meetings and debate, church, home and family life, the use of names, private celebrations, commercial activity (including the posting of signs, accounting, customer service and advertising), news and entertainment media, and citizenship and immigration requirements. ${ }^{9}$ The focus on specific contexts is unsatisfactory, though, because the conclusions drawn do not necessarily translate well from one setting to another.

431, 432 (2000) ("Currently, in the body of norms of international law, the concept of language rights is in an embryonic stage only."); Susanna Mancini \& Bruno DeWitte, Language Rights as Cultural Rights: A European Perspective, in Cultural Human Rights 247, 250 (Francesco Francioni \& Martin Scheinin eds., 2008) (questioning whether a comprehensive or coherent set of language rights exists yet in Europe).

7. Disciplines other than law and political science have addressed many of the same issues that figure prominently in this Article relating to language use and its role in the life of individuals and institutions. For just a sampling of the analyses of other disciplines, see generally DenNIs BAron, THE English-Only Question: An Official Language for Americans? (1990) (public policy); Barry R. Chiswick et al., Immigration, Language and Ethnicity (Barry R. Chiswick ed., 1992) (gathering work of economists, sociologists, and historians); Alejandro Portes et al., The New Second Generation (Alejandro Portes ed., 1996) (gathering work of sociologists and anthropologists); MAnuel Ramirez III \& Alfredo Castaneda, Cultural Democracy, Bicognitive Development and Education (1974) (psychology); Deborah K. Palmer, Building and Destroying Students' 'Academic Identities': The Power of Discourse in a Two-Way Immersion Classroom, 21 Int'l Qualitative Stud. Educ. 647 (2008) (education). Language issues are necessarily inter-disciplinary in nature, and the work of experts in other fields illuminates and informs any discussion of language rights claims. See infra notes 96-99, 109-11 and accompanying text (referencing history, linguistics and sociology scholarship). However, this Article focuses on legal and political theory analyses of language rights claims, because it addresses the question of legal rights relating to language.

8. See, e.g., Juan F. Perea, Ethnicity and Prejudice: Reevaluating "National Origin" Discrimination Under Title VII, 35 WM. \& MARY L. Rev. 805 (1994) [hereinafter Perea, Reevaluating "National Origin" Discrimination] (employment discrimination); Rose Cuison Villazor, Community Lawyering: An Approach to Addressing Inequalities in Access to Health Care for Poor, Of Color and Immigrant Communities, 8 N.Y.U. J. Legis. \& Pub. Pol'y 35 (2004-2005) (health care); Audrey Daly, Comment, How to Speak American: In Search of the Real Meaning of "Meaningful Access" to Government Services for Language Minorities, 110 PENN ST. L. Rev. 1005 (2006) (government services); Lisa B. Ross, Note, Learning the Language: An Examination of the Use of Voter Initiatives to Make Language Education Policy, 82 N.Y.U. L. REv. 1510, 1533-36 (2007) (education).

9. See Alan Patten \& Will Kymlicka, Introduction: Language Rights and Political Theory: Context, Issues, and Approaches, in Language Rights and Political Theory 17-25 (Alan Patten \& Will Kymlicka eds., 2003) (identifying six broad categories of language use that could give rise to rights claims); Manfred Wenner, The Politics of Equality Among European Linguistic Minorities, in Comparative Human Rights 192-93 (Richard P. Claude ed., 1976) (noting and attempting to categorize the broad range of settings in which language use might be "of sociopolitical relevance" to a minority language speaker). 
A few legal scholars in the United States and internationally have taken on the descriptive task of naming the language rights that have been recognized. ${ }^{10}$ However, they have generally not attempted to identify any set of principles for looking at language rights that explains the current treatment of language in the law or that lays out a route for building on or deviating from the status quo to develop a principled framework for addressing language rights.

More recently, some scholars have begun to develop broader theories of language rights, particularly in the arena of political theory. ${ }^{11}$ Their consideration of the theoretical bases for language rights is extremely helpful in considering potential justifications for and limitations on language rights. However, the theoretical work does little to order the current disparate decisions, policies, and norms on language rights. Nor does it get very far in providing a concrete framework for determining which language claims should be treated as rights under the law going forward. ${ }^{12}$

Despite the lack of a coherent language rights framework on any level, distinct approaches to language rights can be discerned in the U.S. legal system and under international human rights law. ${ }^{13}$ The U.S. legal system relies largely on a civil rights framework for addressing language rights, focused most specifically on non-discrimination. ${ }^{14}$ This framework has not necessarily been up to the task of addressing the challenges posed in lan-

10. See, e.g., Del Valle, supra note 5; de Varennes, supra note 6; Arnold H. Leibowitz, Federal Recognition of the Rights of Minority Language Groups (1982).

11. See Patten \& Kymlicka, supra note 9, at 32-51; Cristina M. Rodríguez, Accommodating Linguistic Difference: Toward a Comprehensive Theory of Language Rights in the United States, 36 Harv. C.R.-C.L. L. Rev. 133 (2001) [hereinafter Rodríguez, Accommodating Linguistic Difference]; Cristina M. Rodríguez, Language and Participation, 94 CALIF. L. Rev. 687 (2006) [hereinafter Rodríguez, Language and Participation]. In their 2003 edited volume that gathers for the first time the work of social scientists and political theorists on language rights, Kymlicka and Patten acknowledge that the "field of language rights is a relatively new one...., and to some extent we are still sorting out the relevant questions, let alone identifying the answers." Patten \& Kymlicka, supra note 9, at 51; see also François Grin, Diversity as Paradigm, Analytical Device, and Policy Goal, in Language Rights and Political Theory, supra note 9, at 181 (observing that language rights work "has been taken up by . . normative political science leaning toward political philosophy").

12. The legal theoretical framework for language rights that Rodríguez has progressively laid out helps to bridge the divide between political theory and the law and provides a particularly convincing basis for a broad conception of language rights in the legal system in the United States. However, it does not provide many tools for analyzing specific claims in the range of settings where they arise, nor does it probably intend to do so.

13. This Article uses the term "approach" to describe the general orientation of each system, rather than any high-level theoretical explanation for either system or any specific standard applied consistently in either system. See Multiculturalism and Political Theory 14-15 (Anthony Simon Laden \& David Owen eds., 2007) (defining an approach as "an orientation in thinking rather than a fullblown theoretical apparatus"). The term communicates an important degree of generality. Individual norms, interpretations, and decisions of tribunals do not always hew closely to the general approach of the system in which they arise and diverge significantly from one another within each system.

14. This Article uses the term "non-discrimination" here, rather than "equal protection," advisedly. In the United States, "equal protection" terminology applies to constitutional claims alleging unlawful distinctions made by the government. "Non-discrimination" refers more broadly to the set of prohibitions on discrimination found in statutes and policies as well as the Constitution, which make up the U.S. approach described in this Section. When referencing international human rights law, the 
guage rights analysis. ${ }^{15}$ However, it has had remarkable staying power for the courts and for advocates and policymakers in this country as the vehicle for addressing language-related claims of right.

The international human rights law approach has focused on the cultural identity aspects of language. While provisions explicitly prohibiting discrimination on the basis of language exist in almost all international human rights instruments, those provisions have not been fully or consistently developed. ${ }^{16}$ Instead, the international focus is on respect for language as an essential element of culture and as critical to the maintenance and development of cultural identities.

At least one author, Cristina Rodríguez, has similarly noted the difference in the approaches of the U.S. system and the international human rights framework and described them as focused, respectively, on non-discrimination and cultural rights of minorities. ${ }^{17}$ However, in her important work, Rodríguez emphasizes a significant similarity that she sees in the two approaches. She asserts that they are both essentially "remedial" in nature, attempting to address past transgressions. ${ }^{18}$ From that conclusion, she argues that neither of the approaches adequately frames the most important concerns in the language rights debate, at least in the United States.

Rather than focus on the similarities in the two approaches, which I view as more limited, ${ }^{19}$ this Article utilizes the differences in the approaches as a helpful handle for further development of language rights. Rodríguez does note that the U.S. and international approaches will both "play an important role in any language rights discourse" and considers that a combination of the two might provide a helpful framework for handling language claims, if not a comprehensive theoretical base for language rights. ${ }^{20}$ This Article takes up the task of determining how the two approaches might interact to create a more comprehensive legal approach to language rights and a concrete framework for analyzing claims in the many contexts in which they arise.

Increasingly, national and international legal regimes engage in crossfertilization and exchange. This national/international interaction can, if carefully watched and fostered, lead to the development of more analyti-

Article uses "non-discrimination" and "equal protection" interchangeably, because international human rights law uses both terms to reference the same concept.

15. See infra Part II.A.1 (regarding limitations inherent in the non-discrimination approach).

16. See infra Part II.B.1 (regarding limitations of the international human rights cultural approach).

17. See Rodríguez, Language and Participation, supra note 11, at 693, 697-98, 706, 709.

18. Id. at $693,696-98$.

19. For example, Rodríguez suggests that international human rights law protects only previously repressed national minorities and so parallels the U.S. focus on those who have suffered discrimination. See id. at 697-795. My analysis concludes that international human rights law is more forward-looking and is not limited to the protection of national minorities. See infra notes 43-44, 68-75, 259-67 and accompanying text.

20. Rodríguez, Language and Participation, supra note 11, at 718. 
cally-coherent and rights-protective legal regimes. ${ }^{21}$ Language rights law is an area perfectly suited to development through national/international dialogue. Language is almost always an international as well as a domestic concern. Language issues are entwined with questions of international relations, trans-border cultures, immigration flows and drawing of international borders. Because these issues affect populations in nations around the world, it is important to find solutions on a global level.

This Article thus fleshes out the distinct approaches to language rights employed in the U.S. legal system and the international human rights law regime in the hope that exchange between the two systems might improve the treatment of language rights claims in the United States and internationally. The Article further asserts that consideration of the two regimes reveals much about the factors and considerations that implicitly impact decisions about language rights, which may be made explicit to suggest a doctrinal framework for a more systematic and fair approach to claims of language rights across legal systems.

Section I first describes the U.S. legal system and its non-discrimination approach to language rights and then describes the international human rights framework for addressing language rights with its emphasis on respect for and development of the cultural aspects of language rights. Section II sets out ways in which U.S. and international human rights law can learn from one another and improve their respective systems. It describes some limitations of the non-discrimination approach to language rights and suggests improvements in the U.S. legal system that might be achieved through incorporation of elements of the culture-based international human rights approach. It then identifies weaknesses in the international human rights approach and lays out proposals for improvements based on the welldeveloped non-discrimination framework utilized in the United States. In this Section, the Article thus posits that each legal system should establish protections addressing both non-discrimination and cultural identity concerns in recognizing language rights.

Section III revisits the legal norms and case law of the United States and international human rights regimes to distill the specific factors that are most influential in determining the outcome of language rights claims in the two systems even with their different approaches. A closer look at both

21. See Eyal Benvenisti, Reclaiming Democracy: The Strategic Uses of Foreign and International Law by National Courts, 102 Aм. J. INT'L L. 241 (2008) (describing the phenomenon of international interjudicial exchange); Judith Resnik, Law's Migration: American Exceptionalism, Silent Dialogues, and Federalism's Multiple Ports of Entry, 115 YALE L.J. 1564, 1579-81 (2006) (describing how courts, legislative bodies and executive branch officials can absorb international human rights norms into domestic law); Kent Roach, Constitutional, Remedial, and International Dialogues about Rights: The Canadian Experience, 40 Tex. INT'L L.J. 537, 538-39, 552-55 (2005) (evaluating how interactions between Canadian courts and policymakers and international human rights bodies have led to greater rights protection in Canada); Anne-Marie Slaughter, A Typology of Transjudicial Communication, 29 U. Rich. L. Rev. 99, 132-34 (1994) (asserting that greater national/international communication will cause the "spread and enhanced protection of universal human rights"). 
U.S. law and international human rights law reveals important patterns in the factors influencing language rights decisions that are not readily visible without analyzing the treatment of a broad range of language claims in two different systems. Consideration of these salient factors permits development of a tentative proposal for a doctrinal framework to analyze which language rights should be recognized in the law. The doctrinal framework builds on existing language rights concepts in the U.S. and international human rights systems, as augmented by one another, but proposes the possibility of a more systematic structure for addressing claims of language rights across a range of contexts.

\section{The U.S. and International Human Rights Approaches to LANGUAGE RightS}

\section{A. The U.S. Approach to Language Rights}

In the United States, courts, legislatures, policymakers, and even advocates all use a non-discrimination paradigm for addressing language rights claims. This paradigm treats language as a trait that can inhibit the full exercise of rights and lead to harmful discrimination. It essentially sees language as a disadvantage for non-English speakers, which must be managed until it can be overcome. ${ }^{22}$ Thus, language rights in the U.S. legal system are seen as guaranteeing the right to be free from discrimination on the basis of a lack of English fluency.

Specifically, most legal debate on language rights involves claims about national origin discrimination. ${ }^{23}$ The case law of U.S. courts analyzes language claims framed as national origin discrimination under the Equal Protection Clause to the United States Constitution ${ }^{24}$ or, even more frequently,

22. See BARON, supra note 7 , at 11 (concluding that federal programs have been "transitional" and have been set up to assist nonanglophones until they master English); Rodríguez, Language and Participation, supra note 11, at 697-98 ("[I]n the United States, we frame the language question as a matter of transitioning non-English speaking immigrants . . into a monolingual mainstream . . . [and] the law channels conflict [regarding language] through generally applicable antidiscrimination protections.”); François Vaillancourt, An Economic Perspective on Language and Public Policy in Canada and the United States, in Immigration, Language, and Ethnicity, supra note 7, at 179, 187 (asserting that the "thrust" of U.S. language policy is the promotion of English accompanied by national origin discrimination protections).

23. See Perea, Reevaluating "National Origin" Discrimination, supra note 8, at 809 (noting that the "national origin" label has developed as the primary protection against discrimination because of "ethnic traits"); Juan F. Perea, Los Olvidados: On the Making of Invisible People, 70 N.Y.U. L. Rev. 965 (1995) [hereinafter Perea, Los Olvidados].

24. U.S. CONST. amend. XIV. U.S. courts have resolved a few cases involving language claims on constitutional grounds other than equal protection, particularly using due process and freedom of expression principles. See Yu Cong Eng v. Trinidad, 271 U.S. 500, 528 (1926); Meyer v. Nebraska, 262 U.S. 390 (1923); Maldonado v. City of Altus, 433 F.3d 1294 (10th Cir. 2006); U.S. ex rel. Negron v. State of New York, 434 F.2d 386 (2d Cir. 1970). However, these decisions address a small fraction of the language-related claims that have been raised. The use of principles other than equal protection in these cases does not reflect the approach of the U.S. legal system. 
under the provisions of the Civil Rights Act of $1964^{25}$ prohibiting discrimination in housing, employment and in federally funded programs. Some case law applies state and local anti-discrimination constitutional or statutory provisions. ${ }^{26}$ Advocacy and policymaking revolves around conceptions of non-discrimination based on these same norms.

The use of non-discrimination principles is prevalent across the range of contexts in which language rights claims arise. Thus, the issue of minority language speakers in schools is primarily addressed through the lens of statutory non-discrimination provisions. The seminal decision of the United States Supreme Court in Lau v. Nichols applied the Civil Rights Act to find discrimination on the basis of national origin where non-English speaking children could not equally participate in education because it was provided only in the English language. ${ }^{27}$ That case and the Equal Educational Opportunities Act of $1974,{ }^{28}$ which followed in its wake, continue to frame much of the debate about bilingual education in non-discrimination terms to this day. ${ }^{29}$

Similarly, with mixed results, courts look to the provisions of the Civil Rights Act and parallel state and local laws prohibiting discrimination to determine the legality of English-only workplace rules. ${ }^{30}$ The same provisions are used to address refusals to hire non-English speakers without an objective basis in job qualifications. ${ }^{31}$ These provisions have also served as the basis for courts to strike down differential treatment in the workplace because of foreign accent. ${ }^{32}$

Policymakers and advocates alike also look to discrimination standards in the context of interactions between the government and speakers of languages other than English. In their efforts to seek government benefits and services for individuals who do not speak English, litigants have used the non-discrimination framework. They have argued, with limited success in more recent years, that interpretation and translation services must be pro-

25. 42 U.S.C. $\$ \S 2000$ a to $2000 \mathrm{a}-6,2000$ d to $2000 \mathrm{~d}-7$, 2000e to $2000 \mathrm{e}-17$ (2006).

26. See, e.g., D.C. CODE § 2-1401 (2001).

27. Lau v. Nichols, 414 U.S. 563 (1974).

28. 20 U.S.C. $\$ 1703$ (2006).

29. See, e.g., Horne v. Flores, 129 S. Ct. 2579 (2009).

30. See Maldonado v. City of Altus, 433 F.3d 1294, 1294 (10th Cir. 2006) (holding that Englishonly policy in government workplace constitutes unlawful discrimination); Garcia v. Spun Steak Co., 998 F.2d 1480 (9th Cir. 1993) (holding that English-only rule in the workplace is not actionable discrimination); Garcia v. Gloor, 618 F.2d 264 (5th Cir. 1980) (same); Prado v. Luria, 975 F. Supp. 1349 (S.D. Fla. 1997) (same); EEOC v. Premier Operator Services, Inc., 113 F. Supp.2d 1066 (N.D. Tex. 2000) (holding that English-only rule in the workplace constitutes unlawful discrimination); 29 C.F.R. § 1606.7 (2010) (stating that the EEOC will closely scrutinize English-only rules in the workplace because they are presumed to violate Title VII).

31. See, e.g., Estenos v. PAHO/WHO Fed. Credit Union, 952 A.2d 878 (D.C. 2008) (holding that English fluency requirement in international organization workplace constitutes actionable discrimination).

32. See, e.g., Carino v. Univ. of Okla. Bd. of Regents, 750 F.2d 815 (10th Cir. 1984) (holding that accent discrimination in workplace is unlawful). 
vided to ensure that the government provides access to non-English speakers without discrimination. ${ }^{33}$

Advocates also regularly assert non-discrimination arguments outside of litigation in the context of government services. They argue that nonEnglish speakers are only seeking access without discrimination to the same government services and benefits offered to all residents of the United States, without regard to the language they speak. ${ }^{34}$ For example, several major language minority advocacy groups published a document in 2007 entitled Language Rights: An Integration Agenda for Immigrant Communities, which demonstrates the emphasis on discrimination against non-English speakers. $^{35}$ In setting forth the legal framework for the assertion of a language rights agenda, the publication states: "Since language is often used as a proxy for national origin discrimination, the provisions of [The Civil Rights Act] are critical." 36 The document then describes a portion of its proposed language rights agenda in the following terms: "Providing real opportunities to learn English, not allowing for discrimination, is the most effective means of fostering English proficiency" to ensure participation and success in American society. ${ }^{37}$

In response, policymakers have adopted anti-discrimination reasoning to grant some language rights in certain governmental contexts. In the electoral setting, Congress relied on findings regarding discrimination against language minorities to enact the provisions of the Voting Rights Act that require ballots to be printed in languages other than English in areas with large concentrations of voters who speak a minority language. ${ }^{38}$ Similarly, city and state officials and assemblies, as well as the federal government, have increasingly adopted rules requiring that the government provide language services to non-English speakers in certain circumstances, on the

33. See Alexander v. Sandoval, 532 U.S. 275 (2001) (assuming that refusal to administer driver's license examinations in languages other than English constitutes national origin discrimination, although no private cause of action is available); Soberal-Perez v. Heckler, 717 F.2d 36 (2d Cir. 1983) (denying discrimination claims based on lack of language access to Social Security benefits); Frontera v. Sindell, 522 F.2d 1215 (6th Cir. 1975) (denying discrimination claims based on lack of language access to carpentry appointment exam); Carmona v. Sheffield, 475 F.2d 738 (9th Cir. 1973) (denying discrimination claims based on lack of language access to unemployment benefits); Ramirez v. Giuliani, Stipulation and Order of Settlement, 99 Civ. 9287 (BSJ) (S.D.N.Y. 2001) (settling discrimination claim providing for language services in relation to food stamp benefits).

34. See, e.g., About Us, D.C. Language Access Coalition, http://www.dclanguageaccess.org/cm/ node/3 (last visited Dec. 1, 2010) (describing the coalition's efforts to achieve passage of the D.C. Language Access Act and the organizational goal of ensuring that "all immigrants . . . have access to public services, programs and activities").

35. Mexican American Legal Defense and Education Fund \& The Asian American Justice Center, Language Rights: An Integration Agenda for Immigrant Communities 9, 18 (2007) [hereinafter MALDEF BRIEFING BOOK], available at http://www.advancingequality.org/files/Language_ Rights_Briefing_Book.pdf.

36. Id.

37. $I d$.

38. 42 U.S.C. $\$ 1973$ b (2006); see also LeIBOwITZ, supra note 10, at 6-7 (recounting the debate on the Voting Rights Act). 
grounds that a failure to do so would constitute a discriminatory denial of access to government. ${ }^{39}$

\section{B. The International Human Rights Approach to Language Rights}

The international human rights law regime takes a very different culturebased approach to language rights. Under international human rights law, language and cultural identity are inextricably intertwined, and language rights claims must be viewed in this light.

The culture-based approach to language rights in international human rights law has three basic prongs. First, as essentially a remediation measure, language rights ensure fair and proper treatment of traditionally repressed minorities in order to remove potential sources of conflict in multiethnic societies and thereby protect peace and security. This concern dates back to the Minorities Treaties adopted after World War I ${ }^{40}$ and continues to motivate international human rights law treatment of minority languages. ${ }^{41}$

Second, language rights are intended to guarantee the general civil rights of individuals. Almost all human rights treaties contain a clause prohibiting discrimination on the basis of language and specifically guarantee, without regard to language, the general rights delineated in the instru-

39. See, e.g., Exec. Order No. 13,166, 65 Fed. Reg. 50,121 (Aug. 11, 2000) (mandating recipients of federal funds to provide language services to ensure access to programs without discrimination on the basis of national origin); Enforcement of Title VI of the Civil Rights Act of 1964 - National Origin Discrimination Against Persons with Limited English Proficiency, 65 Fed. Reg. 50,123 (Aug. 16, 2000) (same); CAL. GOv'T CODE $\$ \S 7295-96$ (requiring government services to be provided in languages other than English); S.F., CaL., Admin. Code ch. 91 (2009) (requiring certain government departments to provide information and services in other languages in order to provide equal access to the government); D.C. CoDE $\$ \S 2-1932$ to 2-1934 (2010) (requiring government agencies to provide language services to ensure access to government programs); D.C. OfFice Of Human Rights, LANguage Access in the District: An Annual Compliance Review and 5-Year Checkpoint 5 (2009), available at http://ohr.dc.gov/ohr/frames.asp?doc=/Ohr/lib/ohr/FY09_LA_Compliance_Report_ (Exec_Summary).pdf (describing the purpose of the D.C. Language Access Act as providing limited English proficient individuals with access to government programs "at a level equal to English proficient individuals"); City of New York, Exec. Order No. 120 (July 22, 2008), available at http:// www.nyc.gov/html/imm/downloads/pdf/exe_order_120.pdf (ordering city agencies to provide language services to ensure that "all residents, regardless of their proficiency in English, have meaningful access to City programs, services and activities").

40. See DE VArennes, supra note 6, at 27-28; Louis B. Sohn, The Rights of Minorities, in THE International Bill of Rights: The Covenant on Civil and Political Rights 270 (Louis Henkin ed., 1981); Minority Schools in Albania, Advisory Opinion, 1935 P.C.I.J. (ser. A/B) No. 64, at 4 (Apr. 6, 1935).

41. Declaration on the Rights of Persons Belonging to National or Ethnic, Religious and Linguistic Minorities, G.A. Res. 47/135, Annex, U.N. GAOR, 47th Sess. Supp. No. 49 (Vol. I), U.N. Doc. A/ $47 / 49$ (Vol. 1), at 210 (Dec. 18, 1992) [hereinafter U.N. Declaration on Minority Rights] ("[T]he promotion and protection of the rights of persons belonging to national or ethnic, religious and linguistic minorities contribute to the political and social stability of States in which they live. . .."); see also U.N. Econ. \& Soc. Council, Specific Groups and Individuals: Minorities, ๆ 9 2, 69, U.N. Doc. E/CN.4/ 2006/74 (Jan. 6, 2006) [hereinafter U.N. Minorities Expert Report] (Gay McDougall, Independent Expert). 
ments, such as freedom of expression or due process. ${ }^{42}$ The human rights approach thus acknowledges the possibility of discrimination on the basis of language as well as the reality that general rights may be uniquely denied or limited to language minorities. The approach seeks to counter the problem by injecting an explicit language element into the analysis of equal protection and other individual rights.

Third, language rights seek to guarantee diversity and promotion of multiple cultural identities in a society. ${ }^{43}$ Human rights instruments thus guarantee language rights as a means of protecting the development of cultural identity and thereby also "enriching the fabric of society as a whole." 44

There is no international human rights treaty dedicated to language rights. ${ }^{45}$ However, multiple international human rights norms closely connect language rights with culture. These norms, and the interpretations given to them, establish broad obligations on States to protect and promote the languages and cultural identity of minority language speakers. The main principles are described here, with an emphasis on the United Nations and the European regional system, which have developed specific law relating to language rights, but with mention as well of the Inter-American system as a well-developed regional system with an initial approximation on language rights. ${ }^{46}$

The United Nations ("U.N.") human rights system contains the most obvious expressions of the culture-bound nature of the language rights analysis under international law. Because the United Nations system is the "universal" human rights law regime, its treatment of language rights best captures the approach of international human rights law to language rights. ${ }^{47}$

42. See U.N. Minorities Expert Report, supra note 41, ๆ ๆ 20-21.

43. See infra notes 69-75 and accompanying text; Sohn, supra note 40, at 270; Mancini \& DeWitte, supra note 6 , at $249-50$.

44. U.N. Human Rights Comm., General Comment No. 23, ๆ 9, U.N. Doc. CCPR/C/21/Rev.1/ Add.5 (Aug. 4, 1994) [hereinafter General Comment No. 23].

45. See Mälksoo, supra note 6, at 434.

46. International human rights principles are found in instruments and interpretations ranging from multilateral treaties to adjudicatory decisions to general comments by the various human rights bodies. While not all of these instruments and interpretations are binding on all States, together they form the human rights legal framework. This Section does not draw distinctions based on the binding effect of the various sources of law, because the goal is to describe the overall approach of international human rights law. As compared with the description of U.S. law, this Section emphasizes normative instruments, including treaties and declarations, and interpretative comments by oversight bodies, rather than individual case decisions. This emphasis reflects the fact that international human rights law is largely treaty-based and diverges from the U.S. common law tradition with its development of law through case decisions. Louis Henkin et al., Human Rights, 214-20, 232 (2d ed. 2009).

47. The United Nations system is considered to be "universal" and therefore particularly influential, because it is open to all States, and its core human rights documents lay out the basic standards for human rights worldwide. Id. at 214-20, 232. 
Two of the main U.N. human rights treaties, the International Covenant on Civil and Political Rights ("ICCPR") 48 and the Convention on the Rights of the Child ("CRC"), ${ }^{49}$ explicitly link language and cultural identity in their forceful protection of the rights of language minorities. The ICCPR and the CRC are particularly important in understanding this approach, because the two treaties are among the most widely ratified human rights instruments in the world. ${ }^{50}$ Article 27 of the ICCPR, which is mirrored in Article 30 of the CRC, provides that:

[P]ersons belonging to [ethnic, linguistic, or religious] minorities shall not be denied the right, in community with other members of their group, to enjoy their own culture, to profess and practice their own religion, or to use their own language. ${ }^{51}$

The U.N. Human Rights Committee, charged with interpreting the ICCPR and handling complaints of violations of the treaty, ${ }^{52}$ has further expounded upon the unique cultural approach to language rights envisioned in the treaty. In its General Comment No. 23 on the rights of minorities, the Committee emphasized that Article 27 establishes rights of minority groups, including language rights, which are distinct from other rights established in the ICCPR, such as the right to be free from discrimination on the basis of language and the right to freedom of speech. ${ }^{53}$ The General Comment states that the rights protections provided under Article 27 are "directed to[ward] ensur[ing] the survival and continued development of the cultural, religious and social identity of the minorities concerned." ${ }_{54}$

In addition, the universal U.N. human rights system includes other instruments explicitly tying language rights to respect for cultural identity. These include the 1992 U.N. Declaration on the Rights of Persons Belonging to National or Ethnic, Religious and Linguistic Minorities ("U.N. Declaration on Minority Rights") ${ }^{55}$ and the 2003 U.N. Convention on the Protection of the Rights of All Migrant Workers and Members of Their

48. International Covenant on Civil and Political Rights art. 27, opened for signature Dec. 19, 1966, S. Treaty Doc. No. 95-20, 999 U.N.T.S. 171 [hereinafter ICCPR].

49. Convention on the Rights of the Child art. 30, opened for signature Nov. 20, 1989, 1577 U.N.T.S. 3.

50. See Status of Ratification of the Human Rights Instruments, OfFice OF THE UNITED Nations High COMmissioner FOR HumAn Rights, http://www2.ohchr.org/english/law/index.htm\#core (follow "Status of Ratifications and Signatures of Human Rights Treaties" hyperlink at bottom of webpage) (last updated Nov. 24, 2010).

51. ICCPR, supra note 48, art. 27; see also Convention on the Rights of the Child, supra note 49, art. 30.

52. See ICCPR, supra note 48, arts. 40-45 (establishing functions of the Human Rights Committee); Optional Protocol to the International Covenant on Civil and Political Rights art. 1, opened for signature Dec. 19, 1966, 999 U.N.T.S. 171.

53. General Comment No. 23, supra note 44, ๆ $1,2,5.3$.

54. Id. I 9.

55. See U.N. Declaration on Minority Rights, supra note 41. 
Families (the "U.N. Convention on the Rights of Migrants"). ${ }^{56}$ The 1992 Declaration provides, in its first article, that "[s]tates shall protect the existence and the national or ethnic, cultural, religious and linguistic identity of minorities within their respective territories and shall encourage conditions for the promotion of that identity." 57 Article 31 of the U.N. Convention on the Rights of Migrants obligates States to "ensure respect for the cultural identity of migrant workers and members of their families." 58 Other provisions of the treaty connect "mother tongue" and "culture" and require protection of both. ${ }^{59}$

The regional human rights system for Europe also includes important instruments that tie language and cultural identity. The central instruments on this issue in the European human rights system are the 1998 European Framework Convention for the Protection of National Minori$\operatorname{ties}^{60}$ ("European Framework Convention") and the earlier European Charter for Regional or Minority Languages. ${ }^{61}$ The European Framework Convention sets forth the obligation of States to promote the ability of minorities "to maintain and develop their culture, and to preserve the essential elements of their identity, namely their . . language . . . and cultural heritage."62

As noted above, in addition to the explicit language rights provisions in international human rights law, almost all human rights instruments contain equal protection provisions that include language as a category protected from discrimination. ${ }^{63}$ International human rights bodies inter-

56. See International Convention on the Protection of the Rights of All Migrant Workers and Members of Their Families, adopted Dec. 18, 1990, 2220 U.N.T.S. 3 [hereinafter U.N. Convention on the Rights of Migrants].

57. U.N. Declaration on Minority Rights, supra note 41, art. 1.

58. U.N. Convention on the Rights of Migrants, supra note 56, art. 31.

59. Id. art. 45; see also U.N. Ed., Scientific \& Cultural Org., Convention on the Protection and Promotion of the Diversity of Cultural Expressions, pmbl \& art. 1., Oct. 20, 2005, available at http:// unesdoc.unesco.org/images/0014/001429/142919e.pdf (committing States to "protect and promote the diversity of cultural expressions" and recognizing that "linguistic diversity is a fundamental element of cultural diversity").

60. Framework Convention for the Protection of National Minorities, Feb. 1, 1995, 34 I.L.M. 351 [hereinafter European Framework Convention].

61. European Charter for Regional or Minority Languages, Nov. 5, 1992, E.T.S. No. 148.

62. European Framework Convention, supra note 60, art. 5.

63. See ICCPR, supra note 48, art. 26 ("[T] he law shall prohibit any discrimination and guarantee to all persons equal and effective protection against discrimination on any ground such as . . language .....”); International Covenant on Economic, Social and Cultural Rights art. 2(2), opened for signature Dec. 19, 1966, 993 U.N.T.S. 3 ("[T]he rights enunciated in the present Covenant will be exercised without discrimination of any kind as to . . language."); American Convention on Human Rights art. 1, Nov. 22, 1969, reprinted in Basic Documents Pertaining to Human Rights in the Inter-American System, OEA/Ser.L.V/II.82 doc.6 rev.1 at 25 (1992) ("The States Parties to this Convention undertake to respect the rights and freedoms recognized herein . . . without any discrimination for reasons of . . language .....”); European Convention for the Protection of Human Rights and Fundamental Freedoms art. 14, opened for signature Nov. 4, 1950, 213 U.N.T.S. 221 ("The enjoyment of the rights and freedoms set forth in this Convention shall be secured without discrimination on any ground such as . . . language."). The specific mention of language as a protected characteristic distinguishes international human rights law from U.S. law, which identifies "national origin" but not "language" as a category 
pret the non-discrimination provisions with a distinctly culture-based overlay. ${ }^{64}$

For example, the U.N. body charged with interpreting the International Covenant on Economic, Social and Cultural Rights recently laid out the connection between non-discrimination provisions, language, and culture. In its General Comment No. 20 on Non-Discrimination, the Committee on Economic, Social and Cultural Rights noted that, "[l]anguage barriers can hinder the enjoyment of many Covenant rights, including the right to participate in cultural life." ${ }_{55}$ Similarly, in the case of Lopez-Alvarez v. Honduras, the Inter-American Court of Human Rights found a violation of equal protection with cultural identity impacts when the Honduran State jailed a Garifuna minority rights activist and prevented him from using the Garifuna language while in jail. ${ }^{66}$ The Court took pains to note that "mother tongue represents an element of identity." 67

The focus in international human rights law on culture, including cultural diversity, has important consequences for the language rights approach at the international level. The international human rights culturebased approach to language is not neutral as to the relative protections due dominant and minority languages or as to the debate between assimilation and multiculturalism.

Under international human rights law, the focus is on the protection and promotion of language minorities and their cultural identity. ${ }^{68}$ For instance, the U.N. Declaration on Minority Rights establishes the government's responsibility to foster minority languages by requiring governments not

protected from discrimination. See Perea, Reevaluating "National Origin" Discrimination, supra note 8; Perea, Los Olvidados, supra note 23 and accompanying text.

64. Many international human rights instruments also include provisions regarding language rights in criminal proceedings. These provisions require that charges be explained in a language the criminal defendant understands and that an interpreter be provided if the defendant does not speak the language of the court. ICCPR, supra note 48, art. 14(3)(a), (f); American Convention on Human Rights, supra note 63, art. 8(2)(a); European Convention for the Protection of Human Rights and Fundamental Freedoms, supra note 63, art. 6(3)(a), (e). The cultural approach has not played a significant role in relation to these provisions, because they apply by their terms only to ensure procedural due process to individuals who are not fluent in the court's language.

65. U.N. Econ. \& Soc. Council, General Comment No. 20, ๆ 21, U.N. Doc. E/C.12/GC/20 (July 2, 2009).

66. Lopez-Alvarez v. Honduras, Inter-Am. Ct. H.R. (ser. C) No. 141 (Feb. 1, 2006).

67. Id. \ 169.

68. International human rights law adopts an objective analysis of the relative numbers of people who speak a particular language in a country to determine minority language status, although some human rights bodies and scholars argue in favor of considering the extent to which a language is endangered or subordinated as well. See U.N. Human Rights Comm., Ballantyne v. Canada, I 11.2, U.N. Doc. CCPR/C/47/D/359/1989, 385/1989/Rev.1 (Mar. 31, 1993) (denying an Article 27 claim on the grounds that English speakers are not a "linguistic minority" in Canada and establishing that minority status is determined in reference to numbers throughout the country) \{hereinafter Ballantyne\}; U.N. Minorities Expert Report, supra note 41, ๆ 24 (focusing minority rights analysis on "non-dominant minority groups"); DE VARENNES, supra note 6, at 140-45 (stating that minority language status is based on objective numbers); Mälksoo, supra note 6, at 449-50 (stating that minority status may be a situation-dependent concept). 
only to "protect" the "linguistic identity of minorities" but also to "encourage conditions for the promotion of that identity." 69 In a sign of its concern for promoting minority identities, the Declaration further requires governments to adopt measures intended "to enable persons belonging to minorities to express their characteristics and to develop their culture, language, religion, traditions, and customs." 70

Human rights protection clearly extends to individuals who are monolingual in a minority language. It also must be understood to extend to minority language speakers who become fluent in the majority language or who enjoy a bilingual and bicultural background tying them to both minority and majority languages. ${ }^{71}$ As will be discussed further below, connection to a minority language has significant meaning both for native minority language speakers and the rest of society that does not change with the ability to speak a majority language as well. ${ }^{72}$

Furthermore, while discrimination is prohibited under human rights law without regard to majority or minority status of a language, special measures may be permitted to support the cultural identity of language minorities where they would not be appropriate if used to preserve language majority control. For example, international human rights law specifically allows distinctions based on language to correct conditions that have impaired the enjoyment of minority language rights. ${ }^{73}$

Demanding promotion of language diversity, diverse identities, and multiculturalism, the international human rights law approach emphatically rejects obligatory assimilation. As the United Nations Independent Expert on Minority Issues recently affirmed, the approach repudiates "forced assimilation" into the majority language and culture. ${ }^{74}$ Instead, it empha-

69. U.N. Declaration on Minority Rights, supra note 41, art. 1; see also European Framework Convention, supra note 60, art. 5(1) (requiring promotion of culture and identity, including language).

70. U.N. Declaration on Minority Rights, supra note 41, arts. 2(2), 4(2).

71. DE VARENNES, supra note 6, at 149 (stating knowledge of majority language "should not in itself affect the legitimacy of a claim" to minority language status).

72. See infra notes 83-111 and accompanying text. On the other hand, this Article does not suggest that the cultural identity approach to language rights applies to individuals who do not have a heritage in the minority language even if those individuals become fluent or even bilingual in a minority language. Culture-based language rights protect those who enjoy a connection to a minority language through their family and ethnic heritage. The impossibility of separating the strands of language, family background, ethnicity, and national origin leads to the need for protection and promotion. Use of an adopted minority language does not trigger the same concerns. See Grin, supra note 11, at 171 (highlighting the connection between language and ethnicity and defining ethnicity to include non-elective elements, including language and family, as well as elements assigned as a result of selfperception and perceptions of others); Rodríguez, Language and Participation, supra note 11, at 733, 742 (stating that while individuals can learn new languages, they cannot easily adopt other cultures that they have "neither inherited nor inhabited"); Daniel Weinstock, The Antinomy of Language Policy, in Language Rights and Political Theory, supra note 9, at 250 (stating language provides connection to past).

73. See, e.g., General Comment No. 23, supra note 44, 9 6.2.

74. See U.N. Minorities Expert Report, supra note 41, ๆ ๆ 22(b), 60; see also European Framework Convention, supra note 60, art. 5(2) (demanding that states refrain from "assimilation" of minorities). 
sizes the "value [of] cultural diversity" and "social inclusion" of multiple identities and cultures. ${ }^{75}$

\section{Improvements to Be Made Through a "Bilingual" Approach to Language Rights}

The treatment of language rights in the U.S. and international human rights legal systems could be improved if each of the two systems augmented its current approach to language rights with the approach employed in the other system. This Section addresses some of the improvements that could and should be made through incorporation of a cultural conception into the U.S. legal system and a more stringent nondiscrimination analysis into the international human rights system. The proposal is focused on change in the language rights normative approach in each system rather than change in enforcement mechanisms or in the way specific disputes about language rights should be handled. However, it is very much based on a legal rights analysis of language claims. The implication is that language rights, with their new contours under the recommendations for each system, must be respected or redress must be made available.

Also, the proposal for change suggests a path for development in the overall approach of each system rather than prescribing specific changes in current statutes or treaties, case law, or legal interpretations. In almost any system, though, language rights will be established through a combination of high-level (e.g., constitutional or treaty) and lower-level (e.g., statutes and declarations) norms as well as policies and interpretations.

In urging that the two systems should adopt elements from each other, this Article by no means suggests that either the U.S. legal system or international human rights law addresses language rights perfectly. ${ }^{76}$ It therefore does not argue that the United States should replace its current system through wholesale adoption of the international human rights approach or that the international human rights law system should exactly replicate the non-discrimination framework used in the United States. A basic premise of this Article is that each of the approaches suffers from significant limitations based on its narrow focus ${ }^{77}$ and requires consideration of the other approach to become more multi-dimensional and comprehensive. In addition, justifiable critiques can be levied against each system even when assessed only in terms of what that system intends to be. The suggestion here

75. See U.N. Minorities Expert Report, supra note 41, ๆ 9 3-4, 59-60.

76. See Karen Engle, The Persistence of Neutrality: The Failure of the Religious Accommodation Provision to Redeem Title VII, 76 TEx. L. Rev. 317, 431 (1997) (warning of the danger of using comparison to propose legal reform given the tendency to "valorize the body of doctrine that is being deployed as the alternative model" thereby obscuring problems in the model doctrine).

77. See infra Parts II.A.1. and II.B.1. 
is simply that the U.S. non-discrimination approach provides very helpful and positive conceptions as does the international human rights cultural approach. Each system would benefit from considering those different conceptions as a method for augmenting and improving its own approach to make it more just and coherent. Each of the systems would be better off paying more attention to both non-discrimination and cultural considerations and an exchange between the two should lead to that result.

\section{A. Improvements in the U.S. System through Incorporation of the International Human Rights Law Approach}

In the United States, the current focus on the non-discrimination framework proves superficial and ineffective in addressing the range of complicated claims that arise in the language arena. By incorporating a culturebased approach to language rights, the U.S. legal system could more appropriately handle language claims that arise. This incorporation would allow for more nuanced and, as a result, more exacting inquiries within the antidiscrimination structure that already exists for analyzing language claims. In addition, the consideration of the cultural implications of a language rights legal regime would allow the U.S. legal system to move beyond the current anti-discrimination model to encompass a broader and more responsive understanding of language rights in the law of the United States.

To be clear, this proposal does not require a determination that particular international human rights norms are directly applicable or that the U.S. legal system is currently in violation of international law as a result of the way that it handles language claims. ${ }^{78}$ Instead, the suggestion is that the international human rights law approach should be used to augment U.S. law, because international human rights norms and the approach they embody provide a persuasive and helpful model for consideration.

Key actors in the U.S. legal system, including the United States Supreme Court, have begun to acknowledge the benefits of using international law as a reference point for establishing appropriate standards on difficult legal questions. ${ }^{79}$ Resistance to the use of international law has diminished even

78. Some of the norms cited are binding on the United States under international law. The United States is a party to the ICCPR and has not made any reservations to Article 27 or other relevant treaty provisions, which form the basis of the culture-based approach to language rights. See U.S. Senate Resolution of Advice and Consent to Ratification of the International Covenant on Civil and Political Rights, 138 CONG. REC. 8070 (1992). To the extent the United States is currently not abiding by those international standards through its failure to consider the culture-based impacts of language policy, the United States may in fact be in violation of international obligations, even if direct recourse is not necessarily available.

79. See, e.g., Graham v. Florida, 130 S. Ct. 2011, 2033-34 (2010) (citing to comparative law and international human rights law as a means of informing the Supreme Court's decision regarding the requirements of U.S. law in the criminal sentencing context); Remarks by Sandra Day O'Connor, SouthERn Center for InTERnational StUdies (Oct. 28, 2003), http://www.southerncenter.org/OConnor_ transcript.pdf (discussing the "internationalization of legal relations" and suggesting that the conclusions of other countries and the international community "should at times constitute persuasive author- 
among some long-time skeptics. For example, Supreme Court Justice Antonin Scalia recently acknowledged that international and comparative law may have a role to play in certain disputes with international dimensions. ${ }^{80}$ This Article urges continued movement in this direction as a means of improving the U.S. legal system's handling of vexing language claims. ${ }^{81}$ The international human rights law approach is one of legal rights accepted by countries around the world and so serves as particularly compelling authority. Its character as a legal rights approach also means that it can be integrated into the United States system as a means of completing, rather than transforming, the current legal rights framework for addressing language claims in the United States.

\section{Limitations of the Non-Discrimination Framework}

The current non-discrimination approach to language rights does not allow the U.S. legal system to address even the full breadth of discrimination claims that arise in the United States. As noted above, when it is recognized by the law, language discrimination is treated as national origin discrimination. Under this analysis, the use of a language other than English may be treated as an indicator of national origin that deserves protection as such. However, language is generally treated as a mutable characteristic. The analysis tends to view language as a characteristic connected to national origin but also distinct and changeable in a way that national origin itself is not. For the most part, then, language is recognized as a basis for unlawful national origin discrimination only where English language fluency has not been achieved. ${ }^{82}$

The emphasis on language mutability as part of the analysis of national origin discrimination serves as a serious constraint. The central problem is that language is not mutable in the way the paradigm suggests. ${ }^{83}$ While an

ity in American courts"). Cf. Roper v. Simmons, 543 U.S. 551, 626-27 (2005) (Scalia, J., dissenting) (rejecting international sources); Curtis A. Bradley \& Jack L. Goldsmith, Pinochet and International Human Rights Litigation, 97 Mich. L. Rev. 2129, 2173 (1999) (describing the United States' "resistance" and "disinclination" to applying international human rights law).

80. Mark Sherman, Scalia (Yes, Scalia) Invokes Foreign Law in Court, ABC News (Jan. 12, 2010), http://abcnews.go.com/Politics/wireStory?id=9543044.

81. This Article advocates mutual respect and influence between the U.S. legal system and the international human rights regime. This approach should assuage concerns that international law might displace U.S. law. International law should also adapt based on the influence of U.S. law, making it a less alien source to consider.

82. See Garcia v. Spun Steak Co., 998 F.2d 1480, 1487-88. (9th Cir. 1993); Garcia v. Gloor, 618 F.2d 264, 269 (5th Cir. 1980); Tamar Brandes, Rethinking Equality: National Identity and Language Rights in the United States, 15 Tex. Hisp. J.L. \& Pol'y 7, 41 (2009); Christopher David Ruiz Cameron, How the Garcia Cousins Lost Their Accents: Understanding the Language of Title VII Decisions Approving English-Only Rules as the Product of Racial Dualism, Latino Invisibility, and Legal Indeterminacy, 85 CALIF. L. REV. 1347, 1367 (1997).

83. While a close look reveals that language is clearly not mutable, both those who would limit and those who would expand language rights have suggested that it is. See James Leonard, Title VII and the Protection of Minority Languages in the American Workplace: The Search for a Justification, 72 Mo. L. Rev. $745,745-46$ (2007) (asserting mutability as a reason not to provide protection since "people can learn 
individual can learn English and thus change her language skills, numerous limits on mutability exist. First, it is a lengthy process to learn a new language, making the change less than fully voluntary or even possible for some. ${ }^{84}$ Second, the fact that a minority language speaker learns English in no way changes the fact that the individual is and always has been a native speaker of a non-English language. It is also most often the case that it will be detectable that English is a second language. ${ }^{85}$ Third, even for bilingual individuals, the language used in any particular conversation is not simply a preference or deliberate decision. Instead, it is only a partially volitional result of a variety of factors, such as the speaker's level of comfort in each of her languages, the setting, and the language preference of the interlocutor. ${ }^{86}$ Finally, even for those who speak English, minority language capability and even accent are unavoidably and inextricably tied with ethnic identity and national origin, in the perception both of the minority language speaker and of those around that individual. ${ }^{87}$ Thus, individuals whose native languages are not English possess an immutable characteristic related to national origin even if they may become fluent in English. Discrimination has taken and continues to take place based on this immutable language difference, as it relates to national origin and ethnic identity, and the current system in the United States is not prepared to address the problem.

Also, by making lack of fluency in English the main focus of the language rights regime in the United States, non-English speakers become the central, if not exclusive, holders of language rights, leaving others unpro-

new languages") [hereinafter Leonard, Title VII and Minority Languages]; Rodríguez, Language and Participation, supra note 11, at 692 (identifying a "mutability continuum of language"); Darnell Weeden, Language: The Less than Fair Employment Practice of an English-Only Rule in the Workplace, 7 Nev. L.J. 947, 961 (2007) (asserting mutability of language because language use is "within a person's control" while urging that language be protected because of its connection to national origin). Cf. Perea, Reevaluating "National Origin" Discrimination, supra note 8, at 866 (questioning assumption that language is mutable).

84. See Monica Boyd, Gender Issues in Immigration, in Immigration, Language and Ethnicity, supra note 7, at 328-29 (showing gender disparities in language learning based on opportunity); Chiswick \& Miller, Language in the Immigrant Labor Market, in Immigration, LANGUAGE AND ETHNicity, supra note 7, at 232 (noting correlation between length of time in the United States or Canada and proficiency in English); Ruth Rubio-Marín, Language Rights: Exploring the Competing Rationales, in LANguage Rights and Political Theory, supra note 9, at 70 (noting that learning a second language may not be achievable).

85. Rubio-Marín, supra note 84 , at 63 (stating that people who learn a second language usually do not lose their foreign accents).

86. See Steven W. Bender, Language: Old Hate in New Bottles: Privatizing, Localizing, and Bundling Anti-Spanish and Anti-Immigrant Sentiment in the 21st Century, 7 Nev. L.J. 883, 892-93 (2007) (arguing social science research sets out the concept of code-switching or involuntary switching back and forth between English and a native language); Alfredo Mirando, Now that I Speak English, No Me Dejan Hablar ("I'm Not Allowed to Speak"): The Implications of Hernandez v. New York, 18 Chicano-Latino L. Rev. 115,137 n.145 (1996) (noting that the author, who was raised in Mexico until age nine, can only pray in Spanish even though he now speaks fluent English).

87. See, e.g., Baron, supra note 7 , at xiii, 15; Joshua A. Fishman, The Sociology of Language 4 (1972); see also infra notes $95-113$ and accompanying text. 
tected. The protection of the law, such as it is, only follows a non-English speaker until such time as she becomes fluent in English. ${ }^{88}$ For example, in the context of the workplace, the leading cases hold that English fluency requirements imposed by employers for jobs not requiring English communication skills may constitute unlawful discrimination. However, they hold that English-only workplace rules do not constitute unlawful discrimination when imposed on workers who speak English along with a minority language. ${ }^{89}$ Similarly, in the education context, children speaking minority languages are only guaranteed protection and special consideration, such as English as a Second Language classes or teaching of subject matter materials in their native language, until they speak enough English to participate in regular English-taught classes. ${ }^{90}$

Ironically, the current state of the law sends a message that discourages efforts of minority language speakers to become fluent in English. A language regime should provide opportunities to minority language speakers to learn the majority language and encourage fluency in the dominant language. $^{91}$ Yet, a system that only grants rights to those without fluent English capabilities does not encourage acquisition of the English language in the United States.

More importantly, the current approach fails altogether to consider entire classes of language rights claims based on demands for recognition of the value of minority languages. The focus on those who do not have English fluency allows the system to recognize only the handicap that lack of English capacity can create. The legal analysis explicitly refers to lack of English language capability as a "disability" or "handicap" to be consid-

88. See Rodríguez, Language and Participation, supra note 11, at 706-08.

89. Garcia v. Spun Steak Co., 998 F.2d 1480, 1487-88 (9th Cir. 1993) (holding that non-English speakers cannot converse on the job under an English-only rule but employees fluent in both English and Spanish are not adversely impacted by such a policy because they can comply with the rule and still speak on the job); Garcia v. Gloor, 618 F.2d 264, 269 (5th Cir. 1980) ("The refusal to hire applicants who cannot speak English might be discriminatory if the jobs they seek can be performed without knowledge of that language, but . . . if the employer engages a bilingual person, that person is granted neither right nor privilege . . . to use the language of his personal preference . . ..").

90. See Lau v. Nichols, 414 U.S. 563, 566 (1974) (stating that those who do not understand English find their education experience meaningless without assistance).

91. Advocates and theorists of all persuasions agree on the importance of learning a country's majority language - English in the United States. In support of English language learning as part of a more limited conception of language rights in the United States, see Linda Chavez, Commentary on Part Three, in Immigration, LANGUAgE AND ETHNiCity, supra note 7, at 297-99; James Leonard, Bilingualism and Equality: Title VII Claims for Discrimination in the Workplace, 38 U. Mich. J.L. Reform 57, 126 (2004); Official English, U.S. ENGLISH, http://www.us-english.org/view/8 (last visited Nov. 3, 2010) [hereinafter Official English]. In support of English learning in the context of a broad conception of language rights, see BARON, supra note 7, at 62; Rodríguez, Language and Participation, supra note 11, at 725; Mala Tabory, Language Rights as Human Rights, in Israel Yearbook ON Human Rights (1980); Vaillancourt, supra note 22, at 216, 218. Of course, advocates and theorists seeking a more expansive approach to language rights insist that fluency in the dominant language not be coerced by means that violate rights and also insist on respect for the right to use minority tongues. 
ered in determining whether impermissible discrimination exists. ${ }^{92}$ Even advocates of language rights in the United States often treat minority language use as an impediment that can be resolved by learning English. ${ }^{93}$ They refer to minority language speakers as English Language Learners ("ELL") or Limited English Proficient ("LEP") individuals. ${ }^{94}$ The system simply is not designed to analyze rights claims based on the importance of minority languages to speakers of languages other than English.

\section{Improvements to the Non-Discrimination Framework}

By considering the cultural identity grounding of language claims, the U.S. legal system's framework can respond more effectively and comprehensively to discrimination claims relating to language. By demanding that attention be paid to the cultural meaning attached to language, the new approach will reveal the extent to which cultural bias, relating to national origin, motivates many actions taken against those members of our society who speak another language whether or not they also speak English. At the same time, the approach will allow consideration of the unique and significant harm that occurs, and is experienced as discrimination, whenever actions are directed against the use of a minority language. ${ }^{95}$ In the process, the stranglehold of language mutability is necessarily loosened, allowing much fuller recognition of discrimination on the basis of language as intrinsically tied to national origin.

The treatment of languages other than English in the United States reflects long-standing discriminatory attitudes that have historically connected language, ethnicity and culture. This reality would serve as a crucial reference point under an approach focused on culture and identity.

92. See Horne v. Flores, 129 S. Ct. 2579, 2609 (2009) (Breyer, J., dissenting) (quoting a speech by President Nixon in which he referenced the "language handicaps" of minority language students); Lau, 414 U.S. at 571 (Stewart, J., concurring) (finding it appropriate to require special attention for "linguistically deprived children"); Soberal-Perez v. Heckler, 717 F.2d 36, 43-44 (2d Cir. 1983) (finding no right to language services in interactions with government where "[p]laintiffs' only non-physical disability" is their lack of English); Negron v. New York, 434 F.2d 386, 390 (2d Cir. 1970) (establishing the right to an interpreter in criminal cases because of the "crippling language handicap" suffered by newcomers).

93. See, e.g., Coalition's Letter to City Council Highlights Need for ESL Funding, (June 18, 2008), D.C. Language AcCess Coalition, http://www.dclanguageaccess.org/cm/?q=node/30 (emphasizing desire of immigrants to learn English).

94. See MAldef Briefing Book, supra note 35; Limited English Proficiency: A Federal Interagency Website (Oct. 1, 2010), http://www.lep.gov; Office for Civil Rights, U.S. Dep't Education, http://www2.ed.gov/about/offices/list/ocr/index.html (last modified June 11, 2007).

95. Legal scholars have previously urged convincingly, even without recourse to international human rights law, that national origin analysis should include consideration of language to reach cultural and ethnic identity discrimination. See Bender, supra note 86, at 893; Stephen M. Cutler, A TraitBased Approach to National Origin Claims Under Title VII, 94 YALE L.J. 1164, 1166-67 (1985); Perea, Reevaluating "National Origin" Discrimination, supra note 8, at 857-58, 858 n.267. Such analysis is not precluded by any existing definition of national origin. See Hernandez v. Texas, 347 U.S. 475 (1954) (establishing status of national origin as a protected class but providing no definition of the class); Perea, Reevaluating "National Origin" Discrimination, supra note 8, at 806, 817-21 (finding that legislative history on the meaning of national origin is sparse). 
While from its inception, the United States had a population that spoke multiple languages, ${ }^{96}$ a reaction of suspicion and negative treatment toward those communities whose members spoke languages other than English is equally as historic. ${ }^{97}$ As early as the colonial and independence periods, national leaders urged that the use of the English language reflected the democratic and rational principles of the new nation and promoted loyalty to the United States. ${ }^{98}$ This discourse marked those speaking languages other than English as undesirably foreign and anti-American. The use of minority languages was thus seen as an indicator of a different and more negative culture that English speakers perceived as threatening.

Episodic efforts to repress certain "undesirable" non-English cultures and languages became the pattern in the 20th century. Repressive reactions to languages other than English tracked public and political sentiments directed at specific languages connected to national origin groups viewed as political or cultural threats.

Thus, after incorporating New Mexico, the United States delayed a grant of statehood for another sixty years because of the prevalence of Spanishspeaking residents of Mexican descent in the territory.99 Opposition to statehood was explicitly grounded on the argument that the inhabitants of the Southwest were "unlike us in race, language and social customs." During and after World War I, English-only statutes were passed in an effort to prevent the use of the German language in schools and public debate when German speakers became identified with anti-patriotism. ${ }^{101}$ Similar policies of simultaneous repression of language and culture were adopted against those of Japanese descent in conjunction with World War II. ${ }^{102}$

96. See BARON, supra note 7 , at 87,95 (stating that many government activities took place in German during the 18th and 19th centuries and much of the Southwest conducted its business in Spanish until the 20th century); Del VAlle, supra note 5, at 11-16 (showing that Pennsylvania, California, New Mexico and Louisiana have bilingual backgrounds); Perea, Los Olvidados, supra note 23, at 980 (stating that several states have histories of official bilingualism during the 19th century, including official use of German in Pennsylvania, Spanish in California and New Mexico and French in Louisiana).

97. See, e.g., Perea, Reevaluating "National Origin" Discrimination, supra note 8, at 846-48 (describing patterns of mistreatment of language minorities over the history of the United States).

98. BARON, supra note 7, at 69-73 (stating that as early as the 1700s, German schools sought to instill not only the English language but also democratic ideals understood to accompany English); Perea, Los Olvidados, supra note 23, at 972 (stating that Benjamin Franklin viewed German colonists and their language as a threat to English and to democratic government). See also Leila Sadat Wexler, Official English, Nationalism and Linguistic Terror: A French Lesson, 71 Wash. L. Rev. 285, 294 (1996) (stating that English is still treated as a kind of " "truth language' considered the only appropriate vehicle for the expression of the political ideals of American democracy").

99. Baron, supra note 7, at xv, 101-02; Del Valle, supra note 5, at 14.

100. S. ReP. No. 57-2206, at 9 (1902).

101. Id. at $111-12,143$.

102. Leti Volpp, Impossible Subjects: Illegal Aliens and Alien Citizens: Review of Impossible Subjects: Illegal Aliens and the Making of Modern America by Mae Ngai, 103 Mich. L. Rev. 1595, 1619 (2005) (describing the prohibition on use of Japanese in Japanese-American internment camp leadership councils set up to teach U.S.-style democracy to internees). 
For much of the 20th century, public schools engaged in systematic segregation and exclusion of Mexican-American children and prohibition of use of Spanish in school. ${ }^{103}$ The discrimination derived from a vision of the children as representing a "foreign element" in need of "Americanizing" given their undesirable language and customs. ${ }^{104}$

In recent years, proponents of legislation designating English as the official language of the United States have adopted a tone that is openly critical of specific national origin groups, particularly Latinos. ${ }^{105}$ For example, Senator S. I. Hayakawa, who was one of the founders and most vocal proponents of the movement, claimed that the "aggressive movement on the part of Hispanics . . . to reject assimilation and to seek and maintain . . . a foreign language within our borders is an unhealthy development." 106

Given this history of targeting non-English languages and cultures, it is not surprising that the connections between language and culture continue to motivate negative reactions to minority language use by some. ${ }^{107}$ Those reactions are based on biases against languages spoken by specific national origin groups and the presumptions relating to the culture and identity of those groups that are conjured for some listeners by the use of a nonEnglish language.

Because it is not directed at language per se but rather at culture and national origin, discrimination also does not spare those who speak another language just because they become bilingual in English. As one author has noted, "linguistic minorities face discrimination not just because they do not speak English, but because they do speak another language, which many Americans are not comfortable hearing." 108

In addition to being motivated by cultural biases, actions directed at the repression of other languages have a unique impact on culture and identity, tied to national origin, for those whose language use is called into question. The courts, social scientists, and legal scholars have all recognized that lan-

103. See United States v. Texas, 506 F. Supp. 405, 411-12 (E.D. Tex. 1981) (finding "acute" and "pervasive" discrimination against Mexican-Americans in schools throughout Texas, including de facto segregation into inferior schools and severe punishment for use of Spanish on school grounds), rev'd on other grounds, 680 F.2d 356 (5th Cir. 1982).

104. Id. at 412.

105. See Steve Legomsky, Immigration and Refugee Law and Policy 57 (4th ed. 2004) (arguing that the English-only movement is motivated by anti-immigrant and maybe even anti-Latino sentiment); Wexler, supra note 98, at 295 (stating the U.S. official language movement has a "nationalistic and xenophobic bent").

106. Del Valle, supra note 5, at 57 (quoting S. I. Hayakawa, The Case for Official English (1985)).

107. See Hernandez v. New York, 500 U.S. 352, 371 (1991) (stating that the use of languages other than English "all too often" elicits negative reactions connected to racial hostility); S. REP. No. 94-295, at 30-31 (1975) (finding pervasive discrimination against members of language minorities, particularly those of Hispanic and Asian ethnicity in the Senate Report on the Voting Rights Act).

108. Daniel J. Rearick, Reaching Out to the Most Insular Minorities: A Proposal for Improving Latino Access to the American Legal System, 39 Harv. C.R.-C.L. L. Rev. 543, 544 (2004); see also Baron, supra note 7, at 15 ("For many, knowledge of a language other than English marks them as unassimilated and educationally deficient"). 
guage is connected to identity and culture in an essential, ethnically-bound way. ${ }^{109}$

Sociologist Ruben G. Rumbaut has asserted that "[l]anguage . . . is closely, and affectively, connected to the formation and maintenance of ethnic identity — both within and without the family." 110 In his oft-cited work, sociologist Joshua Fishman stated:

[L]anguage . . . is not merely a carrier of content. . . Language itself is content, a referent to loyalties and animosities, an indicator of social statuses . . . a marker of situations and topics as well as of the societal goals and the large-scale value-laden arenas of interaction that typify every speech community. ${ }^{111}$

Legal philosophers have also emphasized that language "is a marker of identity, a cultural inheritance and a concrete expression of community." The United States Supreme Court has expressed a similar understanding, albeit without recognizing rights on this basis. In Hernandez v. New York, the Court held that "[l]anguage permits an individual to express both a personal identity and membership in a community." 113

Because language is directly linked to membership in national origin and ethnic cultures, actions that limit or punish the use of language call into question an individual's basic identity developed around national origin and language. As one scholar laments: "Telling someone whose culture includes speaking [a particular language] that his language is somehow bad or inferior or illegal sends a deeply humiliating and damaging message." 114

When seen in a cultural light, it becomes evident that the harm resulting from an attack on one's use of a minority language does not diminish when the language user becomes bilingual. The ability to use more than one language does not diminish the importance to an individual of using a native language other than English. Because language is constitutive of one's identity and relationship to others of the same national origin in a common culture, impingement on the use of a speaker's native tongue will always have a severe negative impact. Even if the speaker is able to avoid consequences or punishment for using the native tongue by speaking En-

109. Hernandez, 500 U.S. at 413; Brandes, supra note 82, at 10-11 (stating that language is valuable as cultural inheritance and "marker of identity"); Cameron, supra note 82, at 1364-65 ("Spanish language is central to Latino identity"); Weinstock, supra note 72, at 50 (language provides access to culture and is central to identity).

110. Ruben G. Rumbaut, The Crucible Within: Ethnic Identity, Self-Esteem, and Segmented Assimilation Among Children of Immigrants, in The New Second Generation, supra note 7, at 157.

111. Fishman, supra note 87 , at 4 .

112. Leslie Green, Are Language Rights Fundamental? 25 Osgoode Hall L. J. 639, 659 (1987).

113. 500 U.S. at 370; see also United States v. Texas, 506 F. Supp. 405, 411-12 (E.D. Tex. 1981) (equating language and culture and highlighting damage caused when either is suppressed), rev'd on other grounds, 680 F.2d 356 (5th Cir. 1982).

114. Lupe S. Salinas, Linguaphobia, Language Rights, and the Right of Privacy, 3 STAN. J. C.R. \& C.L. 53, 57 (2007) [hereinafter Salinas, Linguaphobia]. 
glish, the mere fact of being forced into that position of turning one's back on a native language itself causes serious harm to the speaker's core identity. ${ }^{115}$

The current failure of the U.S. legal system to fully recognize the national origin-linked cultural backdrop and effects of language discrimination, resulting from the focus on language mutability, can be remedied. Conscious attention to the cultural aspect of language discrimination claims would force a disavowal of the history of negative cultural stereotyping based on language. It would also require adoption into the discrimination analysis of a more positive view of the role non-English languages and cultures play in societal institutions. Incorporation of the cultural inquiry favored by international human rights law would allow U.S. law to deal more legitimately with language claims arising in employment, housing, and other traditional discrimination contexts. ${ }^{116}$ For example, when employment discrimination claims based on English-only language rules are viewed with an eye to possible motivations based on the connection between language, culture, and national origin, the discrimination inherent in those rules becomes much more evident. And, when considering the impact of the rules on culture, the harm caused by the rules is more obvious. In addition, the distinction drawn between bilingual and monolingual minority language speakers becomes largely irrelevant in the employment context. Court decisions approving English-only rules on the grounds that no harm is caused by requiring bilingual speakers to use English would need to be reconsidered. ${ }^{117}$ This new culture-based approach to employment and

115. Rumbaut, supra note 110 , at 157 (remarking that being forced into speaking English may "entail abandoning not only a mother tongue but also a personal identity").

116. Again, this Article urges supplementing, not replacing, the U.S. non-discrimination approach. The U.S. non-discrimination approach does play an important role in addressing some language claims, where it is applied seriously and with due attention to immutability and other concerns raised here. For example, in the context of access to government services, non-discrimination principles have begun to lead to the provision of interpretation and translation services necessary to allow nonEnglish speakers to interact with the government. See supra note 39 and accompanying text. This resolution seems appropriate and recognizes the immutability of language for non-English speakers seeking to interact with government. Under this analysis, the government may still ask bilingual individuals to use English in interactions with the government where documents and oral communications are not readily available in the minority language. The immutability analysis does not play such a problematic role here. Bilingual speakers of English and another language still bear an immutable characteristic, but they can communicate with the government in English. A requirement that they do so generally does not imply a targeting of the minority language or a rejection of that language as much as a decision regarding use of governmental resources. Of course, if government officials are able and willing to interact with bilingual speakers in a language other than English, a serious non-discrimination analysis with a cultural overlay would preclude impediments to such interactions.

117. Some advocates urge recognition of discrimination in English-only workplace rules even for bilingual individuals by using social science research that suggests that code-switching from one language to another is involuntary. See EEOC v. Premier Operator Services, Inc., 113 F. Supp. 2d 1066, 1070, 1074-76 (N.D. Tex. 2000); Bender, supra note 86, at 892; Weeden, supra note 83, at 960-62. The code-switching argument provides a roundabout way to address the impact of rules that suppress language use, which could be improved by connecting language and culture directly. The argument is also problematic because it treats the use of non-English languages as a negative act that must be 
other discrimination claims challenging restrictive language policies would not only provide redress to victims of such policies but would begin to purge lingering national origin discrimination in the United States.

\section{Improvements Beyond the Non-Discrimination Framework - Recognizing the Value of Minority Languages}

The treatment of language rights as a culture-based concern would also allow the U.S. legal system to move beyond the non-discrimination framework to better consider and handle a broader range of language rights concerns. Simply put, the legal system would evolve from viewing nonEnglish language use only as a handicap in need of dismantling to seeing it as an asset requiring respect and even promotion in some settings. Incorporation of the culture-based focus of the international human rights approach would require the U.S. legal system to ascribe affirmative value to minority languages and cultures. Jury service and education provide two important examples of areas in which this new approach should significantly fortify the rights recognized. ${ }^{118}$

\section{a. Jury Service}

The jury service issue merits attention not because it is among the most frequently raised or even the most serious language rights issues. Rather, a look at jury service is useful because this context illustrates particularly well the conceptions of the U.S. legal system regarding languages other than English and the limitations of the U.S. non-discrimination analysis. It is an area in which adoption of the cultural approach would result in positive and meaningful change.

The current system permits the exclusion from juries of bilingual speakers of English and another language on the basis of their bilingualism. In Hernandez v. New York, ${ }^{119}$ the Supreme Court considered a challenge to peremptory strikes against jurors who spoke both English and Spanish. The Court recognized the close connection between language and race or national origin. However, the Supreme Court held that the strikes were adequately explained as a precautionary measure against the risk that jurors would ignore the official English translation of testimony provided by the court. ${ }^{120}$ Employing a traditional, rigid non-discrimination framework, the

\footnotetext{
forgiven only because it is involuntary. The argument thus runs counter to recognition of the importance of cultural identity expressed through language.

118. As noted above, this Article does not prescribe which norms should be used or adopted to include the cultural analysis. However, the Supreme Court has used constitutional substantive due process and freedom of expression and association doctrines to ensure culture and identity rights in some contexts. See, e.g., Meyer v. Nebraska, 262 U.S. 390 (1923); Maldonado v. City of Altus, 433 F.3d 1294 (10th Cir. 2006).

119. 500 U.S. 352 (1991).

120. Id. at $360-61$.
} 
Court held that the strikes were therefore not intentionally targeted at race and were not violative of the Constitution.

An approach transcending the traditional equal protection analysis and giving full credit to the cultural value of language would reach a different result. The ability to participate in jury service is a fundamental right of citizenship. ${ }^{121}$ When the connection of language to culture is considered, a refusal to allow jury service based on bilingual language ability is revealed as an exclusion from this core right of citizenship based on essential characteristics of culture and identity connected to national origin and ethnicity. Such exclusion should not be permitted.

In addition, viewing the minority language capabilities of bilingual jurors through the cultural lens, fluency in a language other than English should not be seen as a negative factor in the first place. In Hernandez, the Supreme Court assumed that a juror's bilingualism was a serious problem justifying exclusion from service. ${ }^{122}$ Viewed from a cultural perspective, this conclusion is problematic.

First, it devalues the positive contribution that jurors with another language might make. Where the jury will hear testimony by witnesses speaking in a non-English language, a bilingual juror fluent in the language of the witness can play a positive role in helping the jury to evaluate testimony. By hearing the direct testimony as well as the translated testimony, a bilingual juror may be able to perceive errors in translation, which impede understanding of the testimony. The juror may also perceive nonverbal communication important to the speech being conveyed, which will not easily be picked up by jurors hearing the testimony only through translation. ${ }^{123}$ If the translation properly and adequately conveys the testimony given in another language, then the bilingual juror would have little role to play. If the translation is inadequate, then the bilingual juror could play a crucial role in correcting the problem. It cannot be more important for a jury to consider only the official English interpretation of testimony, whether incorrect or not, than to seek out what was actually said and intended. ${ }^{124}$

121. See Akhil Reed Amar \& Alan Hirsch, For the People: What the Constitution Really Says About Your Rights 59-62 (1999) (analyzing jury service as a constitutional right); Del VALLE, supra note 5, at 186 ("The right to sit on a jury is . . a fundamental concept of citizenship ....").

122. 500 U.S. at 360 n.3, 362-63.

123. Muneer I. Ahmad, Interpreting Communities: Lawyering Across Language Difference, 54 UCLA L. Rev. 999, 1037 (2007) ("Nonlinguistic cues are fundamental to the process of making meaning" from utterances).

124. A bilingual juror might well misunderstand the meaning or intention of the testimony due to differences in dialects, vocabulary or culture. A judge might appropriately instruct the jury not to give dispositive weight to a bilingual juror's understanding of the testimony but rather to grant the weight that each juror deems appropriate. The judge could direct the bilingual juror to notify the court and seek clarification if the juror believes the official interpretation is incorrect. 
Second, the ruling leads to the exclusion of specific language-based cultural perspectives from jury deliberations. The Court in Hernandez presumably wished to have all members of the jury hear the same testimony to allow the group to consider the same evidence in deliberations. However, such an ideal is always out of reach even where testimony is given and heard only in English. Because language carries cultural meaning for both speaker and listener, testimony will always be heard differently by each juror based on that listener's own cultural identity and context. ${ }^{125}$ Jurors are expected to bring to bear their perceptions and understandings based on experience as they make determinations regarding credibility and logic. The hope is that the combined perspectives of the various members of the jury will result in accurate fact determinations, or at least determinations that reflect the truth as it would be perceived by members of the community. ${ }^{126}$ As described above, the ability to speak another language leads to the development of a unique cultural identity and social perspective. Inclusion of that perspective should be seen as assisting in fuller and more complete jury deliberation rather than corrupting the process. Exclusion of bilingual jurors removes from consideration a particular perspective based on language, ethnicity and national origin, harming both the excluded juror and the jury process.

Bilingualism should be recognized as adding value to effective jury decision-making. And speakers of languages other than English should be entitled to that recognition as part of a conception of language rights that moves beyond discrimination to encompass the right to cultural identity and thereby embraces multilingualism.

\section{b. Education}

Similarly, in the education context, the law should move beyond the non-discrimination framework and consider the importance of languages other than English to cultural identity. The education arena requires consideration because it is where much of the language rights debate arises in the United States, and the changes wrought by adoption of a cultural approach to language rights would be significant. The goals of the education system would need to shift dramatically toward an emphasis on the cultural

125. See Ahmad, supra note 123 , at 1033 (stating that language is best understood as a social process between speaker and listener in which the listener "can only approximate [the speaker's] meaning, [because] the speaker's intention and the listener's comprehension are both circumscribed by ... . subjective experience").

126. Jeffrey Abramson, We, the Jury: The Jury System and the Ideal of Democracy 10, 11,101 (2000) (arguing that jurors evaluate evidence through personal experience, so inclusion of jurors from a cross section of the community ensures better deliberation and more "reliable and accurate" verdicts); see also Batson v. Kentucky, 476 U.S. 79, 86 n.8 (1986) (emphasizing that a jury must be "drawn from the community" and be "representative"). 
value of language and bilingualism and away from efforts to overcome a "handicap" by replacing minority languages with English. ${ }^{127}$

Cultural identity and connected language use are developed in socially relevant places, such as schools. ${ }^{128}$ In fact, schools often represent the crucial forum in which the determination will be made as to whether or not a minority language will be valued and maintained. ${ }^{129}$

Rejection of a non-English native language in such an important social setting as a school thus raises serious problems. ${ }^{130}$ English immersion programs send a message that English is a valued language whereas minority languages are not only devalued, but are also seen as a handicap. As already noted, severe damage to cultural identity and self-esteem is caused when a characteristic as fundamental as language is rejected.

Respect and promotion of minority languages and cultures will require bilingual education of minority language speakers in their minority languages as well as English. ${ }^{131}$ This is certainly what is envisioned by the international human rights cultural approach to language rights. The U.N. Declaration on Minority Rights specifically provides that: "States should take appropriate measures so that, wherever possible, persons belonging to minorities may have adequate opportunities to learn their mother tongue or to have instruction in their mother tongue."132 Similarly, the Human

127. Numerous models exist for education of minority language students in the United States and even for bilingual education. See, e.g., Ross, supra note 8, at 1533-36. This present Article does not wade into the debate about which is the most desirable model except to note that the culture-based approach requires rejection of models that fail to include the cultural value of language and instead insist on assimilation by minority speakers into English.

128. Rumbaut, supra note 110 , at 157.

129. See Special Rapporteur on Prevention of Discrimination and Protection of Minorities, Study on the Rights of Persons Belonging to Ethnic, Religious and Linguistic Minorities, at 84, U.N. Doc. E/CN.4/ Sub.2/384/Rev.1 (Jan. 1, 1979) [hereinafter Study on the Rights of Minorities] (using minority language in the educational system is a "crucial test" for maintenance of cultural characteristics including language); Rodríguez, Language and Participation, supra note 11, at 758 (arguing that minority language education represents the chief survival mechanism for a language).

130. See United States v. Texas, 506 F. Supp. 405, 420 (E.D. Tex. 1981) (citing expert testimony that "teaching a Spanish-speaking child exclusively in English communicates a powerful message to the child that he or she is a second-class citizen"), rev'd on other grounds, 680 F.2d 356 (5th Cir. 1982); Salinas, Linguaphobia, supra note 114, at 65 (noting the harm to self-esteem caused when a Latino child is taught in school that "speaking Spanish is bad").

131. See DE VARENNES, supra note 6, at 200-02. Bilingual programs that provide instruction in students' native language also appear to be the most effective at teaching English and substantive subject matter. See Del Valle, supra note 5, at 223 (citing to a 1991 Bush administration study establishing that English-exclusive instruction did not assist non-English speakers in catching up to peers); Wayne P. Thomas \& Virginia P. Collier, Ctr. for Research on Educ., Diversity \& Excellence, A National Study of School Effectiveness for Language Minority Students' Long-Term Academic Achievement (2003), available at http://www.usc.edu/dept/education/CMMR/ CollierThomasExReport.pdf (last visited Dec. 3, 2010) thereinafter National Study of Language Minority Achievement].

132. U.N. Declaration on Minority Rights, supra note 41, at 915. 
Rights Committee has expressed concern with education programs focused solely on transitioning minority speakers into the dominant language. ${ }^{133}$

By adopting a bilingual education program for minority language students, the value of non-English languages and cultures is preserved and promoted along with the use of English. As one scholar of education notes, "Should we choose to value the resources of the non-English languages with which the language minority students come to school, we need only to continue providing these students instruction in their native language even as they progress in English." 134

Some detractors oppose bilingual education programs, even in their current limited form, ${ }^{135}$ specifically because they may provide minority language instruction along with English instruction. They complain bitterly that "bilingual education" in the country has "shifted its goals and in many parts of the country has become a native-language maintenance program." 136 Such a critique assumes that assimilation into the English mainstream should be the goal in educating minority language speakers and ignores the negative impact on culture that the assimilationist approach entails. It also ignores the value of cultivating bilingual capabilities among residents of the United States. ${ }^{137}$ Incorporation of the international human rights cultural approach breaks the impasse in favor of native language bilingual education of minority language students.

Under the cultural approach, in addition to providing appropriate bilingual language instruction for monolingual minority language speakers, schools should provide meaningful minority language programs for all students. Thus, minority languages should be taught to students who are monolingual in English as well as to those who are monolingual in a minority language and those who are bilingual in English and a minority language. In this way schools send the message that languages other than English are "worthy of study" and that bilingualism for all should be the goal. ${ }^{138}$ Education for all students in at least two languages will avoid the

133. U.N. Human Rights Comm., Concluding Observations: Latvia, ๆ 20, U.N. Doc. CCPR/CO/ 79/LVA (Nov. 5, 2003) [hereinafter Latvia Concluding Observations].

134. Kenji Hakuta \& Russell Campbell, The Future of Bilingual Education, Consortium Soc. SCI. Ass'Ns Wash. Update 4, 5 (Mar. 22, 1985) (on file with the author). See also Lucinda Pease-Alvarez et al., Spanish Proficiency and Language Use in a California Mexicano Community, $15 \mathrm{Sw}$. J. Linguistics 137 , 148 (1996) (noting that schools foster bilingualism when they provide opportunities for minority language speakers to use their minority language as well as English).

135. See, e.g., Del Valle, supra note 5, at 222 (noting that bilingual education "is not used as a term to describe the goal of fluency in two languages, but as a method to reach . . fluency in English at the expense of retention of the mother language").

136. Chavez, supra note 91 , at 297.

137. See infra note 140 (noting a consensus in the United States regarding the importance of cultivating fluency in languages other than English).

138. Rodríguez, Accommodating Linguistic Difference, supra note 11, at 210; see also Thomas W. Pogge, Accommodation Rights for Hispanics in the United States, in Language Rights and Political THEORY, supra note 9, at 105, 120 (noting that extensive public school instruction in languages other than English would show that the schools are endeavoring to make students competent in important 
situation in which minority language students are alone given the privilege and burden of learning two languages.

The current paradigm for language in education creates a contradiction in which "being bilingual is seen as a mark of intelligence unless you acquire [a non-English language] from your parents as opposed to learning it in foreign language classes."139 Thus, foreign language classes for English speakers are encouraged while bilingual programs that teach English and maintain minority languages meet with disapproval. By viewing early and meaningful minority language instruction to English speakers and non-native English speakers alike as part of a comprehensive language program for all students, the education system will eliminate that paradigm. ${ }^{140}$

This argument in favor of bilingual education for all students does not ignore the reality that it will be impossible for schools to teach fluency in all of the languages currently spoken by students in the public school system. Hundreds of languages are spoken within the United States, ${ }^{141}$ and

minority languages as well as English and would provide a "manifest indication" of the value given to minority languages).

139. Kay Randall, Say What? Bias Against Languages Other than English Hurts Students, Says Scholar, U. Tex. Austin (Jan. 13, 2010), http://www.utexas.edu/features/2009/03/16/language_bias; see also James Crawford, Educating English Learners: Language Diversity in the Classroom (5th ed. 2004) (distinguishing between the devalued "group bilingualism" of minority language communities and the valued "individual bilingualism" of majority language speakers who learn another language); Rodríguez, Accommodating Linguistic Difference, supra note 11, at 216 (noting that the bilingualism of linguistic minorities should be valued and respected to the same degree as the bilingualism of the welleducated).

140. Scholars and advocates alike have recognized multiple benefits to learning languages other than English, which justify mandatory foreign language education by high school in almost all schools in the United States. Bilingual language studies lead to better cognitive skills, knowledge acquisition, and school performance. See Stephen May, Misconceiving Minority Language Rights: Implications for Liberal Political Theory, in Language Rights and Political Theory, supra note 9, at 123, 144, 144 n.15 (noting that "linguistic research over the last 40 years has demonstrated unequivocally that bilingualism is a cognitive advantage rather than deficit"); Alejandro Portes \& Richard Schauffler, Language and the Second Generation: Bilingualism Yesterday and Today, in The New Second Generation, supra note 7, at 8,11 (noting a "positive correlation between academic achievement and bilingualism"). Policymakers have reached a relative consensus on the importance of capability in languages other than English to U.S. interests. See H.R. Con. Res. 3, 111th Cong. (2009) (noting that multilingualism "enhances American competitiveness in global markets" and "improves United States diplomatic efforts"); U.S. Department of Education, Enhancing Foreign Language Proficiency in the United States: Preliminary Results of the National Security Language Initiative (2008), available at http:// www2.ed.gov/about/inits/ed/competitiveness/nsli/nsli-preliminary-results.pdf (introducing President George W. Bush's launch of a major administration initiative to enhance proficiency in foreign languages); Vaillancourt, supra note 22, at 217-18 (recommending bilingual education in Spanish and English from an economic perspective to allow for trade with Latin America). Even advocates of assimilation of minority language speakers recognize the merits of foreign language instruction, at least for native English speakers. See, e.g., Official English: Not "English Only," U.S. English, http://www.usenglish.org/view/11 (last visited Oct. 23, 2010).

141. See Hyon B. Shin with Rosalind Bruno, U.S. Census Bureau, Language Use and ENGLISH-SPEAKING ABILITY: 2000 1-2 (2003) (noting that the official census lists about 380 categories of languages and language families), available at http://www.census.gov/prod/2003pubs/c2kbr-29.pdf. 
any given large urban school district may have students who speak as many as one hundred different languages. ${ }^{142}$

However, the problem is not as great as the numbers might suggest at first glance. The vast majority of minority language speakers are concentrated in one or a few language communities in any particular school or district ${ }^{143}$ with Spanish by far the predominant language in schools around the country. ${ }^{144}$ So, it will generally be possible for a school or district to offer minority language instruction in the languages of the concentrated minority language groups to both English speakers and to those minority language speakers. ${ }^{145}$ The school districts can then provide students who fall into much smaller language groups, of only one or a handful of students, with specialized instruction that meets their need to learn English and to continue to value their own minority language. ${ }^{146}$ The languages of these smaller language groups might not be offered to all students, including English speakers. However, all students would still be taught some minority language in order to ensure respect for the value of languages other than English and bilingualism.

In any case, the differentiation in the exact type of language education provided in different schools in no way detracts from recognition of the right to an education that respects minority languages as an essential element of culture by teaching them. The right should not be viewed as the right to have all students receive education in any particular minority language spoken by students at a school. Instead, the right is to an education that respects and fosters the minority language and identity of each minor-

142. See, e.g., Frequently Asked Questions About Bilingual Education, District of Columbia Public ScHOOLS, http://dcps.dc.gov/DCPS/Learn +About +Schools/Enroll +in +a +School/FAQs +About +Enroll ment/Frequently+Asked+Questions+about+Bilingual+Education (last visited Oct. 23, 2010) (noting that District of Columbia schools enroll students speaking 134 languages); Austin IndePENDENT School District, Board Development: Review of Language Acquisition Programs, Including Dual Language Immersion 4 (2009) (on file with author) (noting that Austin, Texas, schools enroll students speaking 94 languages) [hereinafter AISD Review]; Press Release, Bill \& Melinda Gates Foundation, LAUSD Unveils Major Plan to Improve Academic Achievement in Low-Performing High Schools (Nov. 3, 2005) (on file with author) (noting that Los Angeles schools enroll students speaking 92 languages).

143. See AISD Review, supra note 142, at 4 (noting that while 94 languages are represented in the school district, 95\% of students who speak another language are Spanish speakers); English Language Learners (ELL): Programs and Support, District of Columbia Public Schools, http://dcps.dc.gov/ DCPS/In + the +Classroom/How + Students + Are + Supported/English + Language +Learners $+\% 28$ ELL $\% 29$ (last visited Oct. 23, 2010) (identifying five language groups with significant populations - Spanish, Vietnamese, Chinese, Amharic, and French — in the District of Columbia public school system).

144. National Study of Language Minority Achievement, supra note 131, at 1-2 (Spanish speakers represent $75 \%$ of all language minority students in the United States).

145. See Randall, supra note 139; Rodríguez, Accommodating Linguistic Difference, supra note 11, at 209-10 (emphasizing that the languages involved in bilingual education programs must be determined by the demographics of a geographic location).

146. A school would need to offer some instruction in the minority language, where desired by parents and children, even where only one or a few students speak a particular minority language. In some situations, the necessary instruction might require hiring a special tutor for some hours of the day or week. 
ity language student and that teaches and places value on minority languages for both English dominant and minority language dominant students. As with many other rights, the exact contours of this right in a specific setting depend on a set of variable factors. ${ }^{147}$ However, the essence of the right, as reconfigured in reference to the international human rights culture-based approach, is that determinations regarding language education in any particular local setting must not revolve around the assimilation of minority language students into the English mainstream. Rather, they must also give important weight and consideration to the value of minority languages for all students.

\section{The Consequences of Incorporating the International Human Rights Approach}

In essence, the incorporation of a human rights-based cultural approach to language rights in the United States will provide recognition for the connection between minority languages and cultures and will grant respect to identities based on minority cultures. It would be either disingenuous or undesirably limiting to suggest that the resulting shift in the U.S. legal system will only involve minority language speakers, because they will be the ones to benefit from broader recognition of language rights. A change in approach that requires respect and protection of the cultural identities of minority language speakers does demand something of the majority culture and native English speakers. It obligates an overall shift in the United States toward respect for multiple languages and cultures — towards multilingualism and multiculturalism.

This shift, including the changes urged in the preceding sections of this Article, is not only desirable but possible. Despite a sometimes unhappy history regarding the treatment of non-English languages in the United States, an approach that emphasizes respect for the diversity of languages and cultures falls in line with basic principles of the U.S. legal system. In the last decade, in cases such as Grutter v. Bollinger, the Supreme Court has explicitly recognized the importance of ensuring diversity in our social institutions. ${ }^{148}$ Other courts have mandated respect by government actors for languages other than English even where they simultaneously expressed support for the role of English as a unifying language of common discourse in the United States. For example, in striking down an Arizona Englishonly statute, the Supreme Court of Arizona noted that "the American tradi-

147. See Mathews v. Eldridge, 424 U.S. 319, 335 (1976) (setting out balancing test for determining the contours of due process rights in particular settings). International human rights law addresses the issue in this manner. The European instruments on minority rights use a sliding scale approach by providing for education in minority languages at different levels depending on the size of a particular language minority population and other factors. See, e.g., European Charter for Regional or Minority Languages, supra note 61, art. 8; European Framework Convention, supra note 60, art. 14(2).

148. See Grutter v. Bollinger, 539 U.S. 306, 331-32 (2003); see also Rodríguez, Language and Participation, supra note 11 , at 727-28. 
tion" distinguishes between "encouraging the use of English and repressing the use of other languages." 149 The law in the United States has thus moved in the direction of recognizing language rights, albeit slowly and sporadically. ${ }^{150}$ As described above, the law's handling of language rights claims has nonetheless been compromised heretofore by a failure to appreciate fully the role of culture in language rights claims. For precisely this reason, incorporation of elements of the cultural approach can lead to improvements in the law's treatment of language claims in the United States. It is not unreasonable to believe that courts and policymakers in the United States will consider lessons from international human rights law given the ever-increasing acceptance of the usefulness of international sources in developing U.S. law. ${ }^{151}$

Undoubtedly, there has been some backlash against efforts to secure robust language rights in the United States. Those negative reactions are unlikely to abate any time soon, although anti-multiculturalist beliefs may not be as widely held and accepted today as some would suggest. For example, efforts to pass federal legislation declaring English the official language of the United States have failed, and the courts have struck down state official English language policies where they have more than symbolic impact. ${ }^{152}$ In the end, the assimilationist position does not offer sufficiently weighty arguments to carry the day, as sketched out in the following paragraphs.

In resistance to efforts to secure broader language rights and multiculturalism in the United States, some commentators have raised the specter of a culture war. In fact, in the United States, most culture-based claims regarding language issues have not been made by those who advocate for the rights of minority language speakers based on the connection between lan-

149. Ruiz v. Hull, 957 P.2d 984, 991 (Ariz. 1998) (quoting Yniguez v. Arizonans for Official English, 69 F.3d 920, 923 (9th Cir. 1995) (en banc)); see also Meyer v. Nebraska, 262 U.S. 390, 400-03 (1923) (expressing sympathy for Americanization goals but striking down ban on teaching of foreign languages given that such languages are generally "looked upon as helpful and desirable").

150. See supra notes 30-33, 39 and accompanying text.

151. See supra notes 79-80 and accompanying text.

152. See Josh Hill et al., Watch Your Language! The Kansas Law Review Survey of Official-English and English-Only Laws and Policies, 57 Kan. L. Rev. 669, 674-75, 686-87 (2009). This Article does not dwell on the issue of official English laws, since the provisions left standing do not affect the legal resolution of language matters in a significant way. Official English laws, where passed, have not succeeded in halting the slow trend toward provision of government services in languages other than English, for example. See Ruiz, 957 P.2d at 991, 997 (striking down official English legislation, in part because of its effect on the provision of government services to non-English speakers); Cole v. Riley, 989 So.2d 1001, 1005 (Ala. 2007) (finding that Alabama's official English law did not make unlawful the government's decision to provide driver's license examinations in languages other than English to avoid national origin discrimination). The Article focuses on the law's treatment of particular language rights claims rather than efforts to give English special status, particularly since it does not challenge the conception of English as the de facto common language of the United States. However, English-only legislation, even if symbolic, may in some circumstances have a negative effect on the value afforded to languages other than English under the law. The culture-based approach to language rights would require a close look at such legislation. 
guage and culture. Instead, the culture-based claims are made by those who view preservation of minority languages and cultural identities as a threat to that English language majority culture. ${ }^{153}$ These commentators suggest that minority cultural identities are pitted in battle against the English-speaking majority for recognition in the legal system and society. ${ }^{154}$ They urge assimilation into the majority English-speaking cultural identity as the only acceptable resolution.

For example, academic Samuel P. Huntington readily recognized the connection between language and culture and used this connection to urge protection of a U.S. culture he viewed as tied to the English language. ${ }^{155}$ $\mathrm{He}$ argued that the increasing presence of the Spanish language in the United States as a result of immigration from Mexico meant that "Mexicans pose [a] problem for the United States." 156 For Huntington, immigration by Spanish speakers and an increasing level of bilingualism in the United States constituted "a major potential threat to the country's cultural and political integrity" and "traditional identity." 157 Along these same lines, some members of the U.S. Congress have suggested that efforts to preserve minority languages "devalue" the common culture and language of the United States based on the "common language, English." 158 Columnist David Limbaugh has also decried the "deliberate destruction of the unique

153. Advocates for minority language speakers have largely abandoned the cultural territory to assimilationist advocates by focusing almost exclusively on the non-discrimination framework. See supra notes 22-37, 92-94 and accompanying text. One author describes the emphasis on non-discrimination argumentation as falling into a "doctrinal trap," because it requires making claims of cultural uniformity and universalism when it would be better to seek cultural recognition. Wexler, supra note 98, at 292 n.19; see also Engle, supra note 76, at 433 (arguing that advocates may do a "disservice" by using the language of non-discrimination when they really seek race-conscious measures). Of course, the cultural claims made by assimilationist advocates would be rejected under the international human rights law cultural approach with its emphasis on minority languages and diversity. See supra notes 43-44, 68-75 and accompanying text.

154. Samuel P. Huntington, The Clash of Civilizations and the Remaking of World Order 59 (1996) [hereinafter Huntington, Clash of Civilizations]; Lupe S. Salinas, Language: Immigration and Language Rights: The Evolution of Private Racist Attitudes into American Public Law and Policy, 7 Nev. L.J. 895, 904 (2007) [hereinafter Salinas, Immigration and Language Rights] (quoting newspaper columnist Charles Krauthammer as stating that there is a "real threat to the United States [from] . . . bilingualism and, ultimately, biculturalism”); Samuel P. Huntington, The Hispanic Challenge, Foreign Policy, Mar/Apr 2004, at 30 [hereinafter Huntington, The Hispanic Challenge]; Josh Fund, Op-Ed., English Only Showdown, Wall ST. J., Nov. 28, 2007, at A23 (quoting United States Senator Lamar Alexander); Kent Green, Tancredo Outlines Ills of Illegals in Delta, Montrose Daily Press, Aug. 9, 2005 (quoting United States Representative Thomas Tancredo), http://www.montrose press.com/articles/2005/08/09/local_news/3.txt; David Limbaugh, Editorial, Immigration, Part 2: American Culture, WorldNetDaily (Jan. 14, 2004), http://www.wnd.com/index.php?pageId=22757.

155. See Huntington, Clash of Civilizations, supra note 154, at 59 (asserting that language is one of the "central elements of any culture").

156. Id. at 204

157. Huntington, The Hispanic Challenge, supra note 154, at 33.

158. Fund, supra note 154 (quoting United States Senator Lamar Alexander); see also Green, supra note 154 (quoting then Colorado Congressman Tom Tancredo as stating that the "cult of multiculturalism' . . . teaches ... [that] the Western world has nothing to offer"). 
American culture" through promotion of "multiple cultures and languages." 159

Numerous debates about multiculturalism have taken place in academic discourse, and this Article will not reiterate the points made in those exchanges. ${ }^{160}$ At least in the context of language rights, though, adoption of a cultural approach should not be seen as an attack on the English language or on the cultural identity of English speakers in the United States. The cultural identity approach to language rights should instead be seen as supporting multilingualism and the opportunity for multiple languages and cultural identities to coexist. ${ }^{161}$ The approach may require special rights for minority language speakers to counter the potential of the dominant English language culture to devalue other cultural identities. But, measures taken to protect other languages and cultures in the United States operate only to create room for other languages and to prevent English from holding complete sway in the country. They need not and do not weaken the English language and culture to achieve this result.

Some advocates and scholars have nonetheless argued that a grant of broad language rights to minority language speakers would effect not just a shift, but an unacceptable sea change in the U.S. legal system. This is not the case.

The first concern is that greater respect for minority language rights would lead to Balkanization of the country into a multitude of battling language groups. ${ }^{162}$ Yet, minority language speakers in the United States have never sought to change the status of English as the common language of the United States, which allows for a language meeting point between groups. ${ }^{163}$ The culture-based approach to language rights would not lead to such a change. English will undoubtedly remain the dominant language of the United States as the language used most frequently in public settings and in interactions between members of different language groups. The approach would simply allow language minorities to demand respect for their non-English languages and identities as well.

159. Limbaugh, supra note 154 .

160. See Multiculturalism and Political Theory, supra note 13.

161. See May, supra note 140, at 143 (noting that multiple complementary cultural and linguistic identities can co-exist); Iris Marion Young, Structural Injustice and the Politics of Difference, in Multiculturalism and Political Theory, supra note 13, at 76 (finding that a single polity need not have a single common culture).

162. See Del VAlle, supra note 5, at 63 (presenting arguments of English-only proponents who have asserted the need to put an end to "ethnic separatism"); Salinas, Immigration and Language Rights, supra note 154, at 904 (quoting newspaper columnist Charles Krauthammer who urges assimilation in the United States and describes language differences in Canada as a "plague" and "recurring source of friction"); Official English: Misconceptions About Official English, U.S. ENGLISH, http://www.us-english. org/view/15 (last visited Nov. 3, 2010) ("Without a common language, how long would we remain the 'United' States?').

163. See BARON, supra note 7, at 188 (arguing that no indication exists that Hispanic Americans support linguistic separatism); CHIswick, supra note 7, at 3 (claiming that nobody would argue that there is any real move for official bilingualism). 
A second concern is that a grant of culture-based language rights undermines historic understandings relating to conditional acceptance of immigrants into U.S. society. The conditional acceptance argument posits that, by coming to the United States, immigrants voluntarily accept conditions for their integration, including a requirement that they learn English. ${ }^{164}$ The suggestion is that broad language rights respecting and promoting languages other than English should not be recognized, because such recognition arms immigrants with rights that they should not receive given their conditioned newcomer status. ${ }^{165}$

Immigrants might properly be expected to learn English given that English is the common language of the United States. And they are doing so. Immigrants to the United States continue to learn English at a rapid rate such that the children of immigrants almost always become fluent in English even if the initial immigrants themselves do not. ${ }^{166}$

However, the conditional acceptance argument in no way justifies an assertion that minority language speakers should leave behind their native languages and cultures in addition to learning English. Some commentators use the conditional acceptance argument to insist on English-only rules and the elimination of education programs in languages other than English. ${ }^{167}$ They argue that such measures ensure that immigrants will learn English and integrate into the United States. Yet, arguments assert-

164. See Leonard, Title VII and Minority Languages, supra note 83, at 781 (arguing that immigrants are fairly expected to learn a new language upon arrival since they generally choose to come to a new country); Peter J. Spiro, Questioning Barriers to Naturalization, 13 Geo. Immigr. L.J. 479, 493 (1999) (presenting arguments of assimilationists who assert that individuals who do not speak English cannot join the community of "the American people," which is held together by language, and do not enjoy the rights and privileges of that community); U.S. Commission on ImMigration Reform, Becoming an American: Immigration and Immigrant Policy 25-27 (1997), available at http://www.utexas. edu/lbj/uscir/becoming/full-report.pdf (stating that immigrants come voluntarily and may therefore be required to meet certain "Americanization" expectations, including use of the English language, as part of a "covenant" of expectations between immigrants and the nation).

165. This argument most closely resembles the discussion in the international human rights law arena regarding the extent to which language rights should be granted equally to immigrants and "national minorities." See infra Part II.B.1.

166. See Holt Bleakley \& Aimee Chin, The James A. Baker III Institute for Public Policy at Rice University, What Holds Back the Second Generation? The Intergenerational Transmission of Language Human Capital Among Immigrants 13 (2007), available at http:// bakerinstitute.org/publications/transmission_language_immigrants.pdf (finding that children of nonEnglish speaking immigrants learn to speak English very well by age 13); Richard Alba, Bilingualism Persists, but English Still Dominates, Migration Policy Institute (Feb. 2005), available at http://www. migrationinformation.org/USfocus/display.cfm?ID $=282$ (finding that $92 \%$ of second-generation children of Hispanic immigrants and $96 \%$ of second-generation children of Asian immigrants speak English well or very well); see also Chiswick \& Miller, supra note 84, at 232-37.

167. Chavez, supra note 91, at 297-99 (emphasizing that immigrants should be integrated into society by learning English as the common language and criticizing bilingual education as encouraging retention of native languages); Amy Chua, The Right Road to America?, The Washington Post, Dec. 16, 2007, at B1 (criticizing Spanish-language education of Spanish-speaking children as problematic for ensuring that English remains a common language); Official English, supra note 91 (advocating for official English laws to encourage immigrants to learn English and ensure a common means of communication). 
ing that minority language speakers cannot learn English while maintaining a minority language and culture are so unfounded ${ }^{168}$ as to suggest that they serve as cover for a less palatable position that non-English minorities and cultures are less desirable and should be abandoned. These commentators sometimes counter that immigrants may still use their own languages at home and in family life. However, circumscribing the use of languages other than English to purely private spheres requires effective abandonment of those languages. For a native language to form a meaningful part of life and to provide a cultural context for relations with others, an immigrant must have the opportunity to use that language in important public and quasi-public institutions, such as schools and the workplace. ${ }^{169}$ Prohibitions on non-English language use also lead to loss of capacity to speak those languages. ${ }^{170}$

Furthermore, the relationship between assertions of language rights and the conditional acceptance theory is attenuated. Language rights in the United States are not properly analyzed as an immigration issue alone. Important language communities in the United States, particularly Spanish speakers, pre-date modern immigration and even pre-date the United States as a nation. A significant portion of the United States covers territory that was once held by Spain and Mexico and inhabited by Spanish speakers with a culture and heritage based on that language before the United States even formed. ${ }^{171}$ Spanish speakers cannot then be treated exclusively as an immigrant language community, and they are by far the largest minority language group in the United States. ${ }^{172}$ While many Spanish speakers immigrated to the United States in more recent generations and Spanish speakers continue to arrive every day, language rights claims involving Spanish are still properly rooted in the historic place of Spanish in the

168. Del VAlLE, supra note 5, at 59 (suggesting that, over the past twenty years, the number of bilingual individuals has increased at about the same rate as the number of individuals speaking languages other than English); National Study of Language Minority Achievement, supra note 131; Piatt, supra note 5, at 898 n.68 (quoting The Future of Bilingual Education); Ross, supra note 8, at $1534-36$

169. Rodríguez, Language and Participation, supra note 11, at 735, 757-58.

170. Rumbaut, supra note 110, at 157; Study on the Rights of Minorities, supra note 129, at 84 .

171. See Cameron, supra note 84, at 1360; Perea, Los Olvidados, supra note 23, at 975-77; Salinas, Immigration and Language Rights, supra note 154, at 900-01. Territories obtained by the United States through war and conflict in the 19th century, including the lands that are now the states of California, New Mexico, and Texas, include the greatest concentration of Spanish-speaking populations in the United States today. See SHIN with Bruno, supra note 141, at 4 (stating that the West and South regions of the United States combined have about three times the number of Spanish speakers as the Northeast and Midwest regions combined); Rearick, supra note 108, at 545 (finding that more than one quarter of the populations of New Mexico, Texas, and California speak Spanish at home). See also DeL VAlle, supra note 5, at 20 (describing the conquest of Puerto Rico and the prevalence of Spanish on the island); Salinas, Immigration and Language Rights, supra note 154, at 903 (same).

172. See Shin with Bruno, supra note 141, at 2, 3, 6 (finding that Spanish is the non-English language most frequently spoken at home in the United States). 
United States. ${ }^{173}$ Other languages, including French, ${ }^{174}$ can also claim long-standing minority language histories in the United States and, of course, Native Americans lay an uncontestable claim to status as traditional minority groups in the United States with their own diverse languages. ${ }^{175}$ The scope of language rights cannot be limited through an attempt to conflate language rights with immigrants' rights.

Finally, any conditional acceptance understanding that may exist is limited by the strong non-discrimination tradition in the United States, which ensures that fundamental rights apply to all individuals within the United States regardless of language or immigration status. The U.S. legal system has always granted great power to the government to control immigration $^{176}$ but has also required that constitutional rights be guaranteed to those within our borders, outside of the context of immigration decisions, as a matter of equal protection. ${ }^{177}$ Statutory civil rights protections available in the United States, including the right to non-discrimination, are also generally guaranteed by their terms to all persons within the United States without regard to immigrant status. Thus, for example, the principal federal civil rights statutes establish that "all persons within the jurisdiction of the United States" shall be free from discrimination" 178 and that "no person" shall be discriminatorily excluded from federally funded programs and

173. Contemporary immigration also has connections to the tradition of the Spanish language in the United States. Immigration from Mexico derives from the centuries-old ties that exist between the United States and Mexico and the existence of families and communities spread across both sides of the border. Immigrants from other Spanish-speaking nations come to the United States in part because of the Spanish-speaking heritage here. Even if it were desirable to distinguish between immigrants and historic language communities in determining the rights to be guaranteed, it would be almost impossible to do so on the basis of language, since Spanish and other languages are spoken by both groups. Immigration status would not serve as a feasible proxy either. Some citizens in the United States immigrated within the last five years. Other individuals not recognized as citizens belong to families that have moved for centuries back and forth across the border now dividing the United States and Mexico.

174. See BARON, supra note 7, at 10 (finding that Louisiana had a majority French-speaking population when it was incorporated into the United States).

175. This Article does not address the language rights of Native Americans in any greater depth because the law generally handles the language rights claims of indigenous peoples separately from other language rights questions. See, e.g., Mälksoo, supra note 6, at 454. In addition, U.S. and international human rights law both recognize the culture-based and equal protection rights of Native Americans more readily than other language rights, even if they grant only imperfect protection in reality.

176. Shaughnessy v. United States ex rel. Mezei, 345 U.S. 206, 210 (1953) (reaffirming "the power to expel or exclude aliens as a fundamental sovereign attribute exercised by the Government's political departments largely immune from judicial control”); United States ex rel. Knauff v. Shaughnessy, 338 U.S. 537, 542 (1950) (holding that decisions regarding the exclusion of immigrants are generally not reviewable by the courts, because they involve a "fundamental act of sovereignty" and inherent executive power).

177. See Meyer v. Nebraska, 262 U.S. 390, 401 (1923) ("The protection of the Constitution extends to all, to those who speak other languages as well as to those born with English on the tongue."); Yick Wo v. Hopkins, 118 U.S. 356, 368 (1886) (finding that equal protection is not confined to citizens; the rights of individuals are not less because they are aliens and subjects of another state); $c$. Reno v. American-Arab Anti-Discrimination Comm., 525 U.S. 471, 488 (1999) (holding that immigrants have no right to challenge immigration removal proceedings based on equal protection concerns).

178. 42 U.S.C. $\$ 1981$ (2010). 
services. ${ }^{179}$ Basic non-discrimination conceptions and the universality of rights in the United States ensure that immigrants are included in the protections granted within this country, including broader language rights developed through adoption of a cultural approach. ${ }^{180}$

\section{B. Improvements in the International Human Rights System through Incorporation of U.S. Legal System Conceptions}

In the same way that the U.S. legal system can beneficially be augmented by the international human rights law cultural approach to language, international human rights law can be improved through incorporation of U.S. non-discrimination concepts. Adoption of a more stringent non-discrimination approach, informed by that used in the United States, would better equip international human rights law to address language claims.

Adoption of a rigorous framework for analyzing discrimination will allow for resolution of specific assertions of language rights in a well-reasoned manner that better mediates the competing interests and goals inherent in language rules. At the system level, fuller emphasis on non-discrimination should dispel any remaining doubts about the applicability to immigrants of the full panoply of culture-based language rights guaranteed in international human rights law.

\section{Limitations of the Cultural Approach}

Like the U.S. approach, the international human rights law approach to language rights has serious limitations. First, with its heavy emphasis on culture, the international human rights system has failed to develop a careful non-discrimination analysis to be used in conjunction with the culturebased approach.

International human rights case law and treaty interpretations demonstrate a notable lack of sophistication in dealing with complex discrimination issues, including claims involving language. ${ }^{181}$ The principal problem

179. 42 U.S.C. § 2000d (2010). See Hoffman Plastics Compounds v. NLRB, 535 U.S. 137 (2002) (holding that undocumented immigrants could not obtain certain remedies for violations of federal labor laws, such as rehire, without questioning that they were covered by those laws); Rivera v. NIBCO, Inc., 364 F.3d 1057, 1066-70 (9th Cir. 2004) (precluding discovery of immigration status in employment discrimination litigation because of its irrelevance).

180. This Article does not take up the issue of language fluency as a requirement imposed for citizenship or other immigration benefits. It addresses the range of language rights to be granted to individuals without regard for their immigration or citizenship status and so does not focus on the language component of decisions that determine such status. While the Article does not address eligibility for immigration benefits, it does analyze the right to use one's language in interactions with the government. Interactions with the government may include immigration proceedings.

181. See, e.g., Oddny Mjoll Arnardottir, Equality and Non-Discrimination Under the European Convention on Human Rights (2003) (presenting the case law on equal protection in the European human rights system, which is "typically considered to be unclear and conflicting" and claiming that a "more sophisticated understanding" is required); Daniel Moeckli, Equality and NonDiscrimination, in International Human Rights Law, 207 (Daniel Moeckli et al., eds. 2010) (noting 
is that human rights law does not have a clear set of standards for determining which types of distinctions among individuals involve equal protection concerns nor for determining when distinctions constitute unjustified discrimination and therefore rise to the level of human rights violations.

International human rights law has established that not every distinction constitutes a violation of human rights. The U.N. Human Rights Committee has set out that equal protection does not require "identical treatment in every instance." 182 The regional human rights bodies in Europe and the Americas have similarly established that some distinctions may not involve impermissible discrimination. ${ }^{183}$ The U.N. Human Rights Committee and regional human rights bodies have further set out that differentiation in treatment will not constitute impermissible discrimination "if the criteria for such differentiation are reasonable and objective and if the aim is to achieve a purpose which is legitimate" under the human rights treaties. ${ }^{184}$

In addition, international human rights law specifically provides that special measures, which make distinctions to aid vulnerable individuals, do not generally violate equal protection. The U.N. Human Rights Committee has set out that the principle of equality sometimes requires States to take affirmative action, including "certain preferential treatment . . . as compared with the rest of the population" for periods of time in order to overcome impediments to equality such as past discrimination. ${ }^{185}$ And the U.N. Declaration on Minority Rights provides that special measures taken by States to guarantee language rights "shall not prima facie be considered contrary to the principle of equality." 186

It is not at all clear, however, how these norms interact or what level of rigor should be applied to determine whether a distinction is a violation of equal protection under these rules. For example, confusion exists as to the principle that identical treatment is not required in every case. It is unclear whether distinctions based on differing characteristics are automatically de-

\footnotetext{
“considerable gaps, inconsistencies, and uncertainties" in international human rights law on equality and non-discrimination).

182. U.N. Human Rights Comm., General Comment No. 18, ๆ 8, U.N. Doc. HRI/GEN/1/Rev.1 (July 29, 1994) [hereinafter General Comment No. 18].

183. See Case "Relating to Certain Aspects of the Laws on the Use of Languages in Education in Belgium”, 6 Eur. Ct. H.R. (ser. A) 42-44, 49-51 (1967) \{hereinafter The Belgian Linguistics Case]; Juridical Condition and Rights of the Undocumented Migrants, Advisory Opinion OC-18/03, InterAm. Ct. H.R. (ser. A) No. 18, If 80 (Sept. 17, 2003) [hereinafter Juridical Condition and Rights].

184. General Comment No. 18, supra note 182, ๆ ๆ $, 8,10$, 13; see The Belgian Linguistics Case, supra note 183, at 42-44, 49-51; Juridical Condition and Rights, supra note 183, I 9 84-86; Saramaka People. v. Suriname, Inter-Am. Ct. H.R. (ser. C) No. 172 | 127 (Nov. 28, 2007).

185. General Comment No. 18, supra note 182, ๆ ๆ , 8, 10; see also Organization of American States [OEA], Considerations on the Compatibility of Affirmative Action to Promote Women's Political Participation with Principles of Equality and Non-Discrimination, OEA Doc. L/V/II/106 (1999) (finding that affirmative action might be necessary to achieve equality in unequal situations).

186. Supra note 41, art. 8(3); see also European Framework Convention, supra note 60, art. 4; European Charter for Regional or Minority Languages, supra note 61, art. 7(2).
} 
termined not to constitute discrimination or whether they must also be justified as preferential treatment or as reasonable and objective. ${ }^{187}$ In the same way, international human rights law does not explain whether affirmative action or preferential treatment is: (1) an example of the principle that identical treatment is not required in circumstances that are not identical; (2) a category of objective and reasonable distinction; or (3) a separate justification for differential treatment. ${ }^{188}$ It is also difficult to understand the relationship between the requirements of affirmative State action and the exception to equal treatment requirements for promotion of minority languages. ${ }^{189}$ Limits on the authority to adopt any form of special measure are implicit, for example, in the provision establishing that such measures do not create a "prima facie" violation of equal protection. But those limits are left completely without description. The lack of clarity in the equal protection standards under human rights law makes for messy analysis when applied to language rights. ${ }^{190}$

There has also been much hand-wringing about the status of language rights for immigrants under international human rights law. This ambivalence has limited the ability of international human rights law to respond comprehensively and consistently to language rights claims.

The theoretical work on language rights at the international level has focused on the traditional language minorities of Europe and has thus implicitly or explicitly excluded immigrants from the theoretical justifications for language rights. ${ }^{191}$ International language rights advocacy has not assumed or always sought coverage of immigrants either. ${ }^{192}$ The ambiguity

187. The main statement of equality standards in international human rights law, found in the Human Rights Committee's General Comment 18 on non-discrimination, creates much of this confusion. In separate paragraphs, the Comment establishes: (1) a broad definition of discrimination ( 6 ); (2) the principle that equality does not mean "identical treatment" ( $\mathbf{~ 8 ) ; ~ ( 3 ) ~ t h e ~ r e q u i r e m e n t ~ o f ~ l i m - ~}$ ited-in-time affirmative action measures to eliminate conditions that have perpetuated discrimination ( $\mathbf{1 0}$ ); and (4) the permissibility of differential treatment under criteria that are "reasonable and objective" and necessary to achieve a legitimate aim ( 13 ). Yet, the Comment makes no effort to explain how these various principles interact. General Comment No. 18, supra note 182.

188. Kevin Boyle \& Anneliese Baldaccini, A Critical Evaluation of International Human Rights Approaches to Racism, in Discrimination and Human Rights, 135, 157 (Sandra Fredman ed., 2001) (noting that "affirmative action" principles and modalities in international human rights law are unclear and have not been seriously debated).

189. For that matter, international human rights law creates confusion about what is meant by affirmative State action. The principle of affirmative action sometimes simply relates to a requirement that the State prevent discrimination by private actors. See General Comment No. 18, supra note 182, I 5; General Comment No. 23, supra note 44, ๆ 6.1. Elsewhere, it refers to differential treatment of certain groups as a remedy for past discrimination. See General Comment No. 18, supra note 182, ๆ 10. Various labels then describe this latter form of affirmative action, including "affirmative action," preferential treatment," and "positive measures." General Comment No. 18, supra note 182, ๆ 10; General Comment No. 23, supra note 44, ๆ 6.2.

190. See infra notes $217-24$ and accompanying text for several examples of confusing equal protection analysis by international bodies.

191. See DE VARennes, supra note 6, at 172; Brandes, supra note 82, at 35; Patten \& Kymlicka, supra note 9, at 26-27; Tabory, supra note 91, at 182.

192. In 1996, non-governmental organizations gathered in Barcelona and developed a Universal Declaration of Linguistic Rights as a statement of principles regarding the language rights that should 
in the language rights discourse regarding the proper place of migrants is reflected in international human rights law as set out in treaties and as interpreted by international human rights bodies.

The impact has been the greatest in the European international human rights law system. The European regional system quite blatantly excludes immigrants from language rights. The European instruments focused on minority languages do not apply, by their express terms, to immigrant populations that do not constitute traditional "national" minority groups. ${ }^{193}$

The Inter-American human rights system does not have treaties or interpretations addressing the applicability of language rights to immigrants because it does not have instruments directly addressing language or minority rights at all. However, at the time of the drafting of the ICCPR, and particularly Article 27, States such as Chile and Uruguay opposed the treatment of immigrants in Latin America as minorities entitled to special rights. ${ }^{194}$ The lack of specific delineation of minority rights in treaty law in the Inter-American system may result, at least in part, out of this ambivalence toward immigrants.

The universal human rights instruments and interpretations from the United Nations, including the ICCPR and the instruments that build on that central treaty, now generally grant full language rights to immigrants. However, language rights for newcomers have not always been so clearly established at the United Nations level either.

At the time of the drafting of the ICCPR, there was strenuous debate as to whether the Article 27 minority language protections would apply to immigrant groups. The final resolution of the issue was not completely clear at the time, although language expressly excluding migrants was rejected. ${ }^{195}$ As a result of the debate, some commentators afterwards suggested that migrants were not covered by the provision or, if covered, were not entitled to the same level of protection as national minorities. ${ }^{196}$

The U.N. Human Rights Committee has now issued interpretations leaving no doubt that Article 27 and the other language protection provisions of the ICCPR cover immigrants. In its General Comment 15 inter-

\footnotetext{
be provided under international human rights law. While demanding broad rights for minority language speakers, the Declaration "focuses on the rights of language communities which are historically established in their own territory" rather than on immigrants. Universal Declaration of LinguisTIC RIGHTS, http://www.linguistic-declaration.org/main-gb.htm (last visited Dec. 3, 2010).

193. See European Framework Convention, supra note 60 (applies throughout only to "national minorities"); European Charter for Regional or Minority Languages, supra note 61, art. 1 (specifically excludes "the languages of migrants").

194. DE VARENNES, supra note 6, at 130-34; Sohn, supra note 40, at 274.

195. Sohn, supra note 40, at 279-81; Tabory, supra note 91, at 182.

196. Tabory, supra note 91, at 182. Such suggestions have not subsided altogether. DE VARENNES, supra note 6, at 136-37, 172 (recounting commentaries and suggesting that Article 27 covers nonnational minorities but may only guarantee non-interference rights to immigrants whereas national minorities may claim affirmative support from the government).
} 
preting the equal protection provisions of the ICCPR, the Committee established that "aliens" are protected by Article 27 if they constitute a minority group. ${ }^{197}$ In its General Comment 23, interpreting the parameters of Article 27, the Committee established that Article 27 confers rights on persons who are not citizens of the State party in question. The Committee further held that even migrant workers or visitors in a State party should receive the protection of Article 27 if they constitute a minority group. ${ }^{198}$

The U.N. Declaration on Minority Rights further confirms the general applicability to immigrants of language rights from the universal human rights system. The Declaration, by its terms, builds off of Article 27 of the ICCPR and sets out a broad array of rights that States should ensure for language minorities. ${ }^{199}$ The Declaration makes no distinction between national minorities and immigrants in terms of these rights.

Nonetheless, the historic ambivalence toward the inclusion of language rights for immigrants in the universal human rights instruments of the United Nations still resonates. At least one United Nations human rights instrument continues to make distinctions excluding certain immigrants from some language rights protections. The U.N. Convention on the Rights of Migrants requires States to protect the cultural integrity of all migrants regardless of their status but reserves certain specific language rights to categories of lawful migrants. ${ }^{200}$ This history of ambivalence limits the ability of international human rights law to address the range of concerns affecting immigrants.

\section{Improvements to the Non-Discrimination Analysis Under International} Human Rights Law

While the previous Section of this Article focused on recognition of the cultural identity aspect of language claims as a way to move the U.S. legal system past its narrow focus on non-discrimination, many assertions of language rights do include straightforward allegations of discrimination. Other claims involve equal protection issues even when they are not presented as such. The United States has a highly-developed mechanism for addressing such claims. Consideration of the U.S. legal system's sophisticated structure for addressing discrimination could lead to a more cogent human rights analysis of language rights claims under international human rights law.

197. U.N. Human Rights Comm., General Comment No. 15, ๆ 7, U.N. Doc. HRI/GEN/1/Rev.1 (Apr. 11, 1986).

198. General Comment No. 23, supra note 44, ๆ ๆ 5.1, 5.2.

199. U.N. Declaration on Minority Rights, supra note 41, pmbl. (establishing that the Declaration is "[i]nspired by the provisions of article 27 " of the ICCPR).

200. See U.N. Convention on the Rights of Migrants, supra note 56, arts. 31, 45 (guaranteeing all migrants the right to respect for cultural identity but reserving to documented migrants in regularized status the right to education of migrant children in the "mother tongue and culture"). 
The framework for analyzing discrimination claims in the United States is multi-layered, including in the context of language claims. U.S. nondiscrimination law employs a structured analysis that finds discrimination in a broad range of distinctions but then weighs other values that may be in competition with a strict prohibition on all distinctions in a particular situation. ${ }^{201}$

In brief summary, in the United States, a patchwork of constitutional and statutory provisions address discrimination against protected groups by private and public actors in most areas of life, including employment, government services, housing, and commerce. The law recognizes both intentional differences in treatment affecting individuals with protected characteristics and neutral rules that have a discriminatory impact on protected groups. ${ }^{202}$ Even intentional discrimination does not necessarily require animus against a particular protected group but rather extends to any intentional targeting or distinction based on a protected characteristic. ${ }^{203}$

Under U.S. law, once differential treatment or impact is established, additional analysis determines whether the difference involves a violation of rights. The law considers whether sufficient justification for the discrimination is offered. Where the government has engaged in intentional discrimination, it must provide a compelling governmental interest as a rationale and show that the distinction made is "narrowly tailored" to serve that governmental interest. ${ }^{204}$ Both remediation of past discrimination and protection of diversity may constitute sufficient government interests to justify an intentional distinction. ${ }^{205}$ The government, employer, landlord, or other entity causing a disparate impact must show a program or business necessity or other substantial justification for the rule that creates the discriminatory effect. It must also be established that less discriminatory means are inadequate to meet the proffered purpose of the rule. ${ }^{206}$ If the

201. International human rights law is not completely lacking in similar analytical tools. See supra notes 182-186 and accompanying text. The problem is the lack of clarity and consistency in the international human rights standards.

202. See U.S. Const. amend. XIV; Civil Rights Act of 1964, Pub. L. No. 88-353, 78 Stat. 241 (1964); D.C. Code § 2-1401.01; Adarand Constructors, Inc. v. Pena, 515 U.S. 200, 227 (1995); Village of Arlington Heights v. Metro. Hous. Dev. Corp., 429 U.S. 252 (1977); Washington v. Davis, 426 U.S. 229 (1976); Griggs v. Duke Power Co., 401 U.S. 424, 431-32 (1971); 28 C.F.R. § 42.104(b)(2) (1999). Constitutional equal protection claims require a showing of intentional government discrimination while disparate impact claims proceed under non-constitutional provisions such as the Civil Rights Act and its implementing regulations.

203. See, e.g., Michael Selmi, Proving Intentional Discrimination: The Reality of Supreme Court Rhetoric, 86 Geo. L.J. 279, 288-90 (1997) (gathering and analyzing Supreme Court cases to establish that only differential treatment, and not animus, is required to establish intentional discrimination).

204. See, e.g., Grutter v. Bollinger, 539 U.S. 306, 326 (2003).

205. Id. at 328 .

206. See Alexander v. Sandoval, 532 U.S. 275 (2001) (requiring a "substantial legitimate justification" for a policy with a disparate impact against a protected class and also requiring that such justification be further tested to see whether there exists a "comparably effective alternative practice which would result in less disproportionality"); Griggs, 401 U.S. at 431-32 (finding that, in assessing legality of practices that exclude minorities, "business necessity" is the "touchstone"); Sandoval v. Hagan, 197 
appropriate justification cannot be provided, a discriminatory distinction violates rights protected under the law. ${ }^{207}$

In the language rights context, the Tenth Circuit's decision in Maldonado v. City of Altus ${ }^{208}$ provides a good example of the structure of the analysis under U.S. law. In that case, employees of the City of Altus, Oklahoma challenged a rule adopted by the City that prohibited the use of languages other than English by employees as they worked. The court held that the rule had a negative impact on Latino employees and also possibly resulted from intentional discrimination. It recognized discrimination even though all employees, not just Latinos or Spanish speakers, were bound by the English-only policy. ${ }^{209}$ The court proceeded to analyze the justifications for the rule offered by the City, including assertions that the use of Spanish impeded communication on the City's radio frequency and that non-Spanish speaking employees felt uncomfortable with Spanish in the workplace. ${ }^{210}$ The court held that the City had failed to provide evidence of the legitimacy of these justifications. Thus, the court allowed the action to go to the jury as a claim of unlawful discrimination. Of course, many other U.S. court decisions are less favorable to assertions of language rights. ${ }^{211}$ However, the courts do regularly follow the analytical steps modeled in Maldonado. ${ }^{212}$

Incorporation of basic principles of U.S. discrimination law into the treatment of language claims under international human rights law would lead to broader recognition of instances of discrimination, but would also require a greater depth of analysis by adding an additional step under which justifications must be scrutinized. Possibilities for preferential treatment or legitimate distinctions would be analyzed in this additional step. Under international human rights law, acceptable justifications would include protection of culture and diversity. As in U.S. law, justifications for dis-

F.3d 484, 507 (11th Cir. 1999), rev'd on other grounds sub nom. Alexander v. Sandoval, 532 U.S. 275 (2001).

207. This Section does not adhere to the exact terminology used in the U.S. legal system, such as "strict scrutiny," "compelling governmental interest" or "business necessity." The paraphrased explanation of discrimination standards derives from the insistence that international human rights law need not pattern itself exactly on the U.S. model. Adoption of U.S. terminology would be particularly confusing, because international human rights law already contains its own terminology and structure, even if vague, in this area.

208. 433 F.3d 1294 (10th Cir. 2006).

209. Id. at 1303.

210. Id. at 1306 .

211. See Alexander, 532 U.S. 275 (finding no private right of action to seek administration of driver's license examinations in languages other than English under anti-discrimination statutes); Frontera v. Sindell, 522 F.2d 1215 (6th Cir. 1975) (denying discrimination claims based on lack of language access to carpentry appointment exam); Carmona v. Sheffield, 475 F.2d 738 (9th Cir. 1973) (denying discrimination claims based on lack of language access to unemployment benefits).

212. See, e.g., Frontera, 522 F.2d 1215 (finding discriminatory effect in administration of government professional examination only in English but finding sufficient government justification); Carmona, 475 F.2d 738 (finding a reasonable basis for providing unemployment benefits notices only in English even if the practice involves a discriminatory classification). 
tinctions would be carefully examined to determine whether they are legitimate and whether the distinctions made are closely tied to the stated goals.

\section{a. Official Language Policies}

The new analytical framework would assist in consideration of commonly-raised claims asserting language rights in relation to the language or languages used in interactions between government and the public. The analysis would facilitate fuller consideration of the impact of official language policies requiring use of a majority language in government interactions $^{213}$ but would also allow meaningful inquiry into the rationale behind those policies.

In addressing specific claims of language rights, international human rights bodies have often failed altogether to realize that official language policies will usually create distinctions that trigger equal protection analysis. ${ }^{214}$ They have insisted that human rights law does not "guarantee the right to use a particular language in communications with public authorities." 215 On this basis, they have assumed that official language policies do not implicate discrimination and have not found that official language designations violate language rights. ${ }^{216}$ They have not recognized the discrimination created by policies that allow native speakers of official languages to interact with government in their language, but deny minority language speakers this same possibility.

Thus, in the case of Guesdon v. France, the U.N. Human Rights Committee found no language discrimination issue in a claim brought by a Breton who was denied the right to use his native tongue, rather than French, in a criminal proceeding brought against him. ${ }^{217}$ Invoking the assertion that human rights law does not guarantee the ability to speak in one's language of choice, the Human Rights Committee presumed that no equal protection issue even arises where everyone is required to speak the same language - in this case the dominant French language. ${ }^{218}$

In a particularly interesting official language case, Diergaardt $v$. Namibia, ${ }^{219}$ the U.N. Human Rights Committee used parallel reasoning to address a complaint brought by members of an Afrikaans settler commu-

213. Unlike official English legislation in the United States, which is largely symbolic, the official language policies challenged in the international human rights law system have generally included a more stringent mandate for use of the officially-designated language in public and quasi-public spheres.

214. See DE VARENNEs, supra note 6, at 87-89 (arguing that official language policies constitute preferential treatment of a particular language group).

215. Mentzen v. Latvia, 2004-XII Eur. Ct. H.R. 26; see also U.N. Human Rights Comm., Guesdon v. France, I 10.4, U.N. Doc. CCPR/C/39/D/219/1986 (July 25, 1990) [hereinafter Guesdon].

216. Mancini \& DeWitte, supra note 6, at 248.

217. Guesdon, supra note 215, 9 10.4; see also U.N. Human Rights Comm., TK v. France, U.N. Doc. CCPR/C/37/D/220/1987 (Nov. 8, 1989) (finding inadmissible a petition challenging a French rule that required petitions to the court to be filed in French).

218. Guesdon, supra note 215 , I 10.4 .

219. U.N. Human Rights Comm., Diergaardt v. Namibia, U.N. Doc. CCPR/C/63/D/760/1997 (July 7, 1998) [hereinafter Diergaardt]. 
nity in Namibia. ${ }^{220}$ In Diergaardt, Afrikaaners challenged the designation of English as the official language. The Committee held that a violation of equal protection had taken place. ${ }^{221}$ However, it did not reach this result by holding that the rule mandating the use of English in government affairs resulted in an impermissible distinction between native speakers of English and native speakers of other languages. Rather, the decision relied on the fact that the Afrikaans language was singled out for distinct treatment among the many languages spoken in Namibia, because the Namibian State specifically prohibited civil servants from communicating in the Afrikaans language. 222

Similarly, the European Court of Human Rights found no human rights violations in the case of Mentzen (Mencena) v. Latvia, ${ }^{223}$ which involved legislation establishing Latvian as the official and exclusive language of the government in Latvia. The complaint in this case was filed by a Latvian citizen who was forced by the government to change her German last name in her Latvian passport to comply with Latvian language rules regarding spelling. The Court analyzed the case utilizing a generalized culture-based approach and addressed the right to private and family life. ${ }^{224}$ The Court countenanced the official language policy, emphasizing that it had been adopted for "the preservation and development of the language" in light of the "difficulties the Latvian language had faced during the 50 years of the Soviet regime." 225 The Court did not analyze at all the discrimination issues the rule created by preferential treatment of Latvian.

In each of these cases, a careful equal protection analysis would show that a government requirement of majority language use constituted a language distinction that negatively affected language minorities. Then, an analysis of any justifications for the policies would follow. This analysis would require much more profound consideration of the fundamental issues at play

220. Notably, the U.N. Human Rights Committee did not use a cultural approach to analyze the language claims in either Diergaardt or Guesdon. In Guesdon, the Committee dismissed the portion of the petition alleging violations of Article 27 on the grounds that the facts of the case "did not raise issues under this provision." Guesdon, supra note 215, ๆ 7.3. In Diergaardt, the Committee did not engage in any cultural analysis of the official English rule, although it did consider an Article 27 argument on a completely separate claim relating to land title. Id. $\boldsymbol{\|}$ \ 10.6, 10.9, 10.10. These cases suggest a conclusion by human rights bodies that cultural concerns weigh less heavily when considering claims of right to use minority language in day-to-day interactions with the government. As such, equal protection standards may be seen to adequately resolve these claims. This Article reaches a similar conclusion. See supra note 116, infra notes 292-294 and accompanying text. These few cases do not indicate a withdrawal from the cultural approach in international human rights law, particularly given the minor role of case law in the development of law at the international level. See note 46.

221. Guesdon, supra note 215 , I 10.10 .

222. Id.; see also Diergaardt, supra note 219, Individual Opinion of Rajsoomer Lallah (Dissenting) If 6 (" $[\mathrm{T}] \mathrm{h}$ he gravamen of the reasoning of the Committee lies in that part of the finding which is to the effect that the circular is 'targeted' against the possibility of using Afrikaans in official business .....”). 223. Mentzen v. Latvia, 2004-XII Eur. Ct. H.R. 26.

224. Id. at 28 (stating that language is "closely bound up with the cultural and historical traditions").

225. Id. at 26. 
in language claims. In some cases, unlawful discrimination would be revealed where it was otherwise not visible, increasing human rights protection. For example, in Mentzen, a serious non-discrimination analysis would likely have led to a finding of human rights violations, since the justification for the official language rule involved the protection of a majority (not a minority) language while less harmful alternatives, other than a forced name and identity change, almost certainly existed to promote recovery of the Latvian language even if that goal were deemed legitimate. In other cases, the outcome might not change under a deeper equal protection analysis, but the analysis would be much more transparent for the parties and would aid in the consolidation of human rights law on language rights.

The Diergaardt case provides the best example of the importance of the equal protection analysis in improving consideration of language claims. If the Human Rights Committee had found discrimination in the official English rule, it would have proceeded to consider the justifications for the policy. The analysis would have been extremely useful, since the government's motivations in Diergaardt bring up multiple important issues arising in language rights claims.

Governmental justifications would likely have included the need to unify a relatively recently formed State with multiple ethnic minorities and the importance of correcting the previously existing situation of colonialism and domination by Afrikaaners. One member of the Human Rights Committee noted that the case involved the tension between the new "unified nation" and the older system of "privileged and exclusive status . . . enjoyed" by the Afrikaaners under apartheid.226 Finally, the government likely would have urged financial and logistical limitations as a reason for insisting that government interactions take place in a single language.

The assertion of a need for linguistic unity would not have provided a legitimate justification without more, because international human rights law specifically requires respect for minority languages and promotion of multiculturalism. And it would certainly be possible to designate a unifying language but also allow for government interactions in other languages under certain circumstances.

Nor could the policy have been permitted as a correction or accommodation based on the history of apartheid in Namibia. Analysis of that justification would have noted that promotion of minority languages is a legitimate goal and even a right under international human rights law where that promotion remedies past discrimination or preserves diversity. ${ }^{227}$ Yet, that analysis would have necessarily concluded that, here, Namibia did

226. Diergaardt, supra note 219, Individual Opinion of Rajsoomer Lallah (Dissenting) I 9.

227. Several years after the Diergaardt decision, the U.N. Human Rights Committee highlighted Namibia's obligation to promote minority languages and noted the potential negative impact of the English-only rule on that obligation. See U.N. Human Rights Comm., Concluding Observations: Namibia, I 21, U.N. Doc CCPR/CO/81/NAM (July 26, 2004) thereinafter Namibia Concluding Observations]. 
not design the policy to meet such legitimate goals. The policy required that English alone be used in the government rather than requiring that the government respond in the range of Namibian minority languages or otherwise promote those languages. To the extent the policy addressed history and the cultural value of language, it appears to have been punitive against the Afrikaans rather than restorative or constructive of minority languages in general.

Finally, financial considerations could not have been deemed sufficient to justify the policy requiring use of English in all interactions with the government. Conservation of government resources might be a legitimate governmental goal in some circumstances, particularly in interactions between the government and individuals who speak the official majority language as well as a minority language. However, a requirement that the government act only in a single language without accommodation for monolingual minorities leads to the complete exclusion of such monolingual speakers, on a discriminatory basis. An analysis, akin to that required under U.S. law, would require consideration of the connection between the proffered goal and the means used to meet it as well as an inquiry into the existence of other measures that might less seriously impact rights. Such an analysis would conclude that the English-only policy is not sufficiently necessary to the goal of conserving resources. Other mechanisms, which would be less harmful to non-English speakers, could be used to limit expenditures. Namibia could have adopted a rule providing that government would generally be conducted in English but that steps would be taken to allow monolingual minority language speakers to interact with the government in their language. The government could adopt measures that would not be prohibitively costly, such as use of public personnel who are bilingual in minority languages or use of interpreters and translators. ${ }^{228}$ The facts present in the Diergaardt case make this point particularly clear. The decision indicates that oral interactions in the Afrikaans language could have taken place at no cost, because many civil servants spoke the Afrikaans language. ${ }^{229}$

The resolution of the Diergaardt case, then, would probably have been the same under a full equal protection analysis. However, by giving them full attention, the handling of all of the relevant issues would have been significantly improved.

\section{b. Government Language Rules in the Quasi-Public Sphere}

The handling of discrimination issues arising out of government regulation in the quasi-public sphere could also be greatly improved through application of multi-step scrutiny modeled on U.S. non-discrimination

228. See, e.g., id. \ 21 (urging the development of translation services to allow government interaction with minority language speakers); Latvia Concluding Observations, supra note 133, ๆ 19.

229. See Diergaardt, supra note 219 , ๆ 10.10 . 
analysis. The treatment by the U.N. Human Rights Committee of the case of Ballantyne v. Canada ${ }^{230}$ illustrates the need for this more exacting analysis.

The petitioners in Ballantyne were business owners in the province of Quebec in Canada; their mother tongue was English and their clients were also largely native English speakers. They challenged legislation applicable in Quebec that prohibited them from using English for purposes of advertising, including a ban on the inclusion of English in commercial signs. ${ }^{231}$ In addressing their claim of discrimination, the U.N. Human Rights Committee held:

[The] prohibition [on discrimination] applies to French speakers as well as English speakers. . . Accordingly, the Committee finds that the authors have not been discriminated against on the ground of their language. ${ }^{232}$

The Committee again failed altogether to acknowledge the very different impact that the language rule prohibiting the use of English would have on an English-speaking businessperson serving English-speaking clients as compared to a French-speaking businessperson. As a result, it did not consider whether any governmental justification existed for the differential treatment. ${ }^{233}$

Consideration by the U.N. Human Rights Committee of the justifications offered for the commercial signage legislation in Ballantyne would again have helped to set out guideposts for States. The justification would presumably have been one of protection and promotion of French given its historically vulnerable status in Canada. ${ }^{234}$ An analysis of the discrimination claim would likely have found this objective to be legitimate. In this case, however, the measures taken would likely be deemed unjustified, because they entail significant intrusion on the rights of English speakers in

230. Ballantyne, supra note 68. Before assessing the equal protection claim, the Human Rights Committee considered and rejected an Art. 27 claim on the grounds that English speakers are not a minority in Canada. Id. $\mathbb{\text { I } 1 1 . 2 .}$

231. $I$ d. 93.1 .

232. Id. 11.5 .

233. The U.N. Human Rights Committee has not changed its approach to the question in more recent years. In 2003, the Committee again considered the French language requirements for commercial signs in Quebec. U.N. Human Rights Comm., Hoffman v. Canada, U.N. Doc. CCPR/C/84/D/ 1220/2003 (Aug. 5, 2005). The Committee dismissed the case for lack of exhaustion of domestic remedies but expressed no interest in revisiting its determination that equal protection was not at issue. See id. ๆ 7.2. It is worth noting a specific example of how the same issue would be handled differently under a more exacting U.S. law discrimination analysis. In Asian American Business Group v. City of Pomona, 716 F. Supp. 1328 (C.D. Cal. 1989), Asian business owners challenged an ordinance that required one half of all text on signs placed at commercial premises to be written in English characters. The court held that the ordinance "expressly" discriminated on the basis of national origin. Id. at 1332. The court then held that the ordinance constituted unlawful discrimination, because the government failed to establish that it was narrowly tailored to meet a substantial government interest. Id.

234. The Committee considered and rejected this justification in its treatment of the claim to freedom of speech. Ballantyne, supra note 68 , $₫$ \ 11.3, 11.4 . 
the semi-private commercial sphere and are not tightly connected to the goal of French language promotion. Other less intrusive means of protecting the French language are almost certainly available, given the questionable role of signage as a tool for granting value to language.

\section{Improvements in the Treatment of Immigrants as Minority Language Speakers}

Integration of more stringent U.S. non-discrimination considerations into international human rights law would also clarify that members of immigrant communities should enjoy the full panoply of language rights, including those guaranteed under the international human rights cultural approach. International human rights law recognizes that language rights are central to human dignity and to diversity. ${ }^{235}$ International human rights law also explicitly mandates equal protection and provides that the rights it guarantees, which include language rights, may not be denied to entire categories of persons. ${ }^{236}$ Taking this directive seriously, as equal protection is taken in the United States, requires that the same language rights be guaranteed to immigrants as to individuals in other language communities.

The suggestion that States may not be required to ensure full language rights for immigrants under international human rights law is based on a distinction made, particularly by scholars of political theory, between two levels of rights. At the first level, there is no doubt that all language speakers, including immigrants, should receive protection against discrimination and violations of other basic rights that may involve harm to members of certain language groups or targeting of those groups. However, some theorists suggest that there exists another more expansive layer of rights that should only apply to traditional "national" minorities. ${ }^{237}$ Some authors distinguish between the two layers as "tolerance-oriented rights" and "promotion-oriented rights" while others describe "instrumental" rights as opposed to "non-instrumental rights." 238 These labels refer variably to rights granted in the private sphere versus the public sphere, ${ }^{239}$ rights of non-

235. See supra notes $43-44,68-75$ and accompanying text.

236. See supra note 63.

237. See DE VAREnNES, supra note 6, at 172; Mälksoo, supra note 6, at 449; Patten \& Kymlicka, supra note 9, at 26-27; Tabory, supra note 91, at 182. Kymlicka has defined national minorities as groups existing in a territory before the current majority obtained control. See Patten \& Kymlicka, supra note 9, at 26. At times, he has added a further requirement of colony or conquest by the majority. See Will Kymlicka, Multicultural Citizenship 79 (1995) (identifying national minorities as those whose homeland has been incorporated through conquest, colonization or federation).

238. Patten \& Kymlicka, supra note 9, at 26-27 (describing tolerance vs. promotion-oriented rights); Rubio-Marín, supra note 84, at 56-68 (describing instrumental vs. non-instrumental rights).

239. Mälksoo, supra note 6 , at 450-51 (referencing the distinction made between tolerance-oriented rights and promotion-oriented rights); Patten \& Kymlicka, supra note 9, at 26-27 (contrasting right to private language choices with right to use of a particular language in and by public institutions). 
interference versus rights that require expenditures of public funds, ${ }^{240}$ or non-discrimination rights versus cultural self-reproduction rights. ${ }^{241}$ The descriptions of which rights are guaranteed at the higher level are unclear, but the additional rights presumably include more extensive rights to recognition of the cultural identity value of minority languages and to active promotion of language as culture. Thus, the distinction asserts the inapplicability to immigrants of all or part of the culture-based analysis that is so central to the international human rights law approach to language rights.

Proponents of the distinction essentially suggest that the obligations of the state at the higher level of language rights are too expansive and costly to be justifiably applied beyond national minorities. ${ }^{242}$ The distinction arises out of an understanding by at least some theorists that language rights have a reach so extensive that they require granting autonomy or semi-autonomy to national minorities in certain regions of a country ${ }^{243}$ or mandating that the government conduct business in all or part of the country in minority languages. ${ }^{244}$ Given this broad understanding of the language rights entailed, theorists have suggested that it would be impossible or inappropriate to grant similar rights to immigrants. ${ }^{245}$

Yet, international human rights law does not envision language protection and promotion measures as extensive as those suggested by these theorists for any language group, even with its broad cultural approach. ${ }^{246}$ The theorists arguing applicability of broad language rights only to national

240. DE VARENNES, supra note 6, at 172-73 (distinguishing between right of non-intervention in minority language use and use of "state resources" or "state largesse" to support minority language use).

241. Rubio-Marín, supra note 84, at 56; see also Will Kymlicka, The New Debate on Minority Rights (and postscript), in Multiculturalism and Political Theory, supra note 13, at 38-40 (distinguishing between fair integration rights of immigrants and nation-building rights of national minorities) [hereinafter Kymlicka, The New Debate].

242. See DE VARENNES, supra note 6, at 135-36, $144 \mathrm{n} .46$ (suggesting that Article 27 of the ICCPR applies to immigrants only because it contains essentially only negative obligations); see also Patten \& Kymlicka, supra note 9, at 26-27, 36 (claiming that expansive language rights may only be extended to certain language communities and the distinction between immigrants and national minorities is most frequently used in determining which communities should be privileged).

243. Kymlicka, The New Debate, supra note 241, at 38-40 (positing national minorities' right to self-government).

244. Rubio-Marín, supra note 84, at 56-58 (suggesting that non-instrumental rights include the right to have one's language treated as official and to have it used by government authorities).

245. DE VARENNES, supra note 6 , at 172 (finding that greater rights requiring expenditures of public funds may be granted to national minorities, but not to non-national minorities); Kymlicka, The New Debate, supra note 241, at 38-40 (juxtaposing immigrants' right to integration on fair terms with national minorities' right to measures of self-government); Rubio-Marín, supra note 84, at 56-58 ("non-instrumental" rights such as official language declarations for minority languages are generally limited to language groups recognized as autochthonous).

246. Part of the confusion regarding the reach and application of international human rights law arises because scholars have not always explained whether they are offering political theories that describe just language policies or normative arguments describing legal rights. See Mälksoo, supra note 6, at 463-64 (noting failure in the literature to distinguish between human rights based in international law and political preferences); Patten \& Kymlicka, supra note 9, at 26 (noting ambiguous relationship between language policy and language rights yet frequently mentioning language "rights"). 
minorities have focused heavily on language rights concerns in Europe. ${ }^{247}$ With their eyes trained on Europe's traditional national minorities clustered in specific geographic areas, such as Yiddish-speaking Jews in Poland or the Catalans of Spain, the theorists developed conceptions of language rights that focus on autonomy and broad official language rules. ${ }^{248}$ As a political matter, these theorists may rightfully urge self-government and mandatory official use of minority languages in the contexts they have addressed. ${ }^{249}$ However, such proposals must be fought out in the political arena, because international human rights law does not make such broad claims cognizable as rights. ${ }^{250}$

While Article 27 of the ICCPR emphatically requires promotion of the diversity of languages and cultural identities and demands positive measures for that purpose, ${ }^{251}$ these requirements have always had limits. ${ }^{252}$ Even the European human rights instruments that provide perhaps the broadest directive for affirmative action by governments and expenditures of funds in support of minority languages, while requiring those actions only for national minorities, have significant limits. For example, the European Framework Convention does not impose a broad mandate requiring government entities to interact with minorities in their own languages. Instead, it much more modestly requires governments "as far as possible" to establish conditions allowing for the use of a minority language in interac-

247. See Grin, supra note 11, at 175 (demonstrating graphically how different disciplines focus their analysis of language issues on particular geographic regions and connecting international law studies to the national minorities of Europe).

248. See Brandes, supra note 82 , at 27-28 (stating that "territorial autonomy" has been "the predominant model for recognizing non-instrumental language rights").

249. See Patten \& Kymlicka, supra note 9, at 26 (recognizing that rights are only part of the discussion). International human rights law likely would not prohibit expansive recognition of the languages of traditional national minorities where the political will exists to provide it, particularly where there has been a history of repression. Special preferences granted by the State to vulnerable national minorities would probably not violate equal protection standing alone, because they would be justified as a means of removing impediments to full enjoyment of language by the minority groups. However, special measures that failed to take into account the language rights of others, including immigrants, would violate equal protection. For example, a special provision granting official language status to a national minority language could not prohibit or hamper the rights of other minority language users to use their language and interact with the government in the minority language where necessary, without running afoul of a serious equal protection analysis.

250. Other human rights provisions might provide greater support for autonomy for certain national minorities. Some groups might even make self-determination claims to partial or full independence. See ICCPR, supra note 48, art. 1. Neither the equal protection nor cultural approach to language rights provides a base for such claims, though.

251. See General Comment No. 23, supra note 44, ๆ 6.1, 6.2 (requiring positive measures to allow language minorities to develop their cultural and language identities); $c f$. DE VARENNES, supra note 6, at 134, 136 (arguing that States accepted Article 27 because it requires government restraint rather than public support but failing to explain how the author derives broad promotion rights for national minorities); Sohn, supra note 40, at 284 (finding that Article 27 will not generally entail support from public funds).

252. See U.N. Declaration on Minority Rights, supra note 41, art. 4(3) (invoking Article 27 to require states to teach minority languages only "wherever possible"). 
tions with the government. ${ }^{253}$ This requirement is further conditioned by the caveat that it applies only if the minority language community makes a request for such government action that "corresponds to a real need." 254 Finally, international human rights law emphatically does not mandate that States permit secession or even self-governance by language minority groups. ${ }^{255}$

Once language rights are properly delimited under international human rights law, the principles of equal protection should be understood to prohibit distinctions between the rights of immigrants and other language minorities. ${ }^{256}$ In other words, limiting boundaries for language rights under international human rights law should and do exist but cannot be drawn so as to exclude immigrant minority language speakers as a group. ${ }^{257}$ The delimited, but still significant, language rights provided under international human rights law, including culture-based rights, must be guaranteed to immigrants as well as national minorities.

The exclusion of immigrants is particularly difficult to justify under an exacting equal protection analysis, because the bases for recognition of culture-based language rights often apply equally to immigrant groups and to national minority groups. Immigrant languages are certainly tied to culture and therefore to identity and human dignity in the same way that national minority languages are. Similarly, the value of immigrant languages to cultural diversity cannot be differentiated from the diversity value of national minority languages. ${ }^{258}$

Many of the same remediation concerns about persistent injustice faced by individual minority speakers and their communities also apply to immigrants. Immigrants around the world face significant discrimination, including on the basis of language and culture, and immigrant groups are often marginalized from mainstream society or even subjected to violence. $^{259}$ In some ways, immigrants may be more of a target of repression

253. European Framework Convention, supra note 60, art. 10.

254. Id.

255. See Mälksoo, supra note 6, at 464; see also European Framework Convention, supra note 60, art. 21 (stating that minority rights do not allow acts contrary to sovereignty and territorial integrity); U.N. Minorities Expert Report, supra note 41, I 26 (declaring that human rights instruments do not require grants of "territorial or non-territorial autonomy to minority groups" or the creation of "self-governing arrangements").

256. See Sujit Choudhry, National Minorities and Ethnic Immigrants: Liberalism's Political Sociology, 10 J. Pol. PHIL. 54, 56, 65 (2002) (claiming that distinction made by Kymlicka and others between rights of national minorities and ethnic minorities to language promotion appears to be "discriminatory" and unjustified).

257. See Patten \& Kymlicka, supra note 9, at 27 (arguing that distinction between immigrants and national minorities in assigning tolerance and promotion rights is a political preference).

258. In some situations, such as in the United States, immigrants and national minorities form the same minority language group. See Mancini \& DeWitte, supra note 6, at 256 (finding in some cases it is "almost impossible to draw a convincing dichotomy between 'native' and 'new' minorities"). See also supra notes $171-75$ and accompanying text.

259. See, e.g., Salinas, Immigration and Language Rights, supra note 154, at 912-17 (describing history of discrimination against Latinos in the United States); Christian Caryl \& Akiko Kashiwagi, This is 
and marginalization, and thus in greater need of full protection, in countries that have finally come to peace with their national minority language groups. $^{260}$

Even the same concerns regarding the need to promote minority languages and multicultural understanding as a means of maintaining peace and unity may apply to immigrants. Riots and violence by immigrants and anti-immigrant nationals alike have taken place in countries, such as France and South Africa, where the government has taken insufficient action to promote respect for minority languages and cultures. ${ }^{261}$

Finally, the proposed distinction between levels of rights available to immigrants and national minorities fails to recognize the difficulties with the distinction itself. ${ }^{262}$ Non-discrimination and promotion rights are not so easily separated. ${ }^{263}$ Particularly because international human rights law requires recognition of the cultural identity aspects of language, even in the equal protection context, claims of minority language speakers to promotion of their languages may be framed in non-discrimination terms. For example, members of a minority language community may claim a right to education in their native language, generally assumed to be a promotionbased right, on equal protection grounds. These minority language speakers may assert that education provided exclusively in the majority language denies them an equal right to education, because they cannot benefit from the education offered to the same degree as majority language speakers. ${ }^{264}$ On the other hand, State decisions to grant cultural promotion rights to traditional minority groups might lead to discrimination claims by immigrants. The national minority/immigrant distinction would not help in sorting out which rights would be owed to immigrants in compliance with equal protection obligations and which would be denied as higher level

the New Japan, Newsweek, Sept. 11, 2006, at 22 (describing marginalization and mistrust of Brazilian immigrants in Japan); Sandip Roy, Italy's Media Wrestle with Immigrant Bashing, New American Media (Nov. 24, 2009), http://news.newamericamedia.org/news/view_article.html?article_id $=17 \mathrm{~d} 484248 \mathrm{cb}$ $9571 \mathrm{~d} 5 \mathrm{fa} 5782 \mathrm{e} 08 \mathrm{~d} 36 \mathrm{ff} 5$ (describing immigrant bashing in Italian press and society); France Riots: Understanding the Violence, CBC News (Nov. 28, 2007), http://www.cbc.ca/news/background/paris_riots (describing widespread immigrant riots in France attributed to the marginalization of North African immigrant families); Violence Spreads Across South Africa, CNN.com (May 23, 2008), http://www.cnn. $\mathrm{com} / 2008 / \mathrm{WORLD} / \mathrm{africa} / 05 / 23 /$ southafrica.violence/index.html (reporting on violence against immigrants in South Africa).

260. See Kymlicka, The New Debate, supra note 241, at 52 (finding that many Western democracies are "increasingly comfortable" with recognition of rights for "historic minorities" but not for immigrants).

261. See France Riots: Understanding the Violence, supra note 259; Violence Spreads Across South Africa, supra note 259.

262. Indeed, this Article argues throughout that a better analysis considers discrimination and cultural promotion issues jointly.

263. See, e.g., Brandes, supra note 82 , at 29 (finding that most rights have both "instrumental" and "non-instrumental" dimensions).

264. See DE VARENNES, supra note 6, at 200-02 (arguing equal protection principles would require education in native tongue where minority group is large enough); Rubio-Marín, supra note 84, at 64 (acknowledging that anti-discrimination measures must include accommodations for minority languages in order to root out all societal discrimination, including in education). 
cultural promotion rights. ${ }^{265}$ To avoid these difficulties and to make international human rights law more coherent and fair, any lingering distinction between immigrants and national minorities should be definitively rejected with the aid of a serious non-discrimination approach derived from U.S. law.

\section{The Consequences of Incorporating the U.S. Non-Discrimination Approach}

As with incorporation of the culture-based approach into the U.S. legal system, international human rights law would not be drastically changed through incorporation of a more stringent non-discrimination analysis based on the U.S. approach. ${ }^{266}$ The adaptations to international human rights law are, then, eminently feasible.

The incorporation of a more structured analysis for the handling of specific language claims involving equal protection would not require significant changes in international human rights law. The revised analytical structure would simply make better use of existing norms and standards regarding non-discrimination to handle these claims rationally and fairly.

No dramatic changes would be required to grant full culture-based language rights to immigrants under international human rights law either. At the universal level, the shift effected by including immigrants in the full range of language rights would be more one of perception of the law rather than one of changing relevant norms and interpretations. As described above, at the universal level, it is now clear that the human rights treaties do not exclude immigrants from the full culture-based array of language rights despite any proffered theoretical distinctions.

Further adjustment might be necessary in the regional human rights systems to ensure language rights coverage for all minority languages, including immigrants, upon adoption of a more stringent equal protection approach. The limitations on language rights for immigrants found in European human rights law would need to be removed. Despite the restrictive language in European treaties and other instruments, there is a movement afoot by European courts and treaty bodies to extend language rights more fully to immigrants. ${ }^{267}$ Attention to equal protection concerns must push this movement along more rapidly.

265. On the other hand, as noted above, a serious equal protection analysis might lead to a determination that special measures for national minorities are acceptable or even required in specific cases. See supra note 249. However, the national minority/immigrant distinction alone is not useful for this purpose.

266. Also, as with the incorporation of international human rights law principles into U.S. law, insistence on mutual respect between the U.S. and international human rights systems should ease the incorporation of U.S. principles into international human rights law. Those who fear U.S. hegemony should be reassured to see the exchange between international law and U.S. law as a "two-way street" in which each system influences, rather than dominates, the other.

267. See Stella Burch Elias, Regional Minorities, Immigrants, and Migrants: The Reframing of Minority Language Rights in Europe, 28 BeRKELEY J. INT'L L. 261, 312 (2010). 
The Inter-American human rights system has not had occasion to expound upon language rights but has held generally that "the migratory status of a person can never be a justification for depriving him of the enjoyment and exercise of his human rights." 268 The contemporary InterAmerican human rights system would likely include immigrants as beneficiaries of a full range of language rights, but it would be helpful for the system's bodies to provide guidance on this point.

\section{Initial Proposal for the Development of a Doctrinal FramewOrK FOR LANGUAgE Rights}

Side-by-side dialogic consideration of the international human rights and U.S. approaches to language rights yields another valuable benefit beyond the identification of possible means for improvement in the general approaches of each of the two systems. The study of the U.S. and international human rights systems together reveals distinct patterns in the factors that are most important and influential in determining what language claims are accepted as reflecting legitimate rights. In turn, those patterns permit the development of the beginnings of a doctrinal framework for determining what language rights should be recognized in the law.

Such a doctrinal framework has thus far been elusive. ${ }^{269}$ The existing theoretical scholarship offers very little assistance in determining how language rights theories would be operationalized. In other words, the theories do not address what specific factors would determine which language rights should be granted under the law in the range of contexts in which language claims arise on the ground. The initial proposal for a doctrinal framework suggested in this last Section seeks to supply the theories, and even the general approaches suggested in this Article, with a scheme for determining what specific legal rights should be recognized. The tentative framework proposed is offered as a starting point for further development.

\section{A. Identification of the Most Salient Factors Impacting Recognition of Specific Language Rights}

In-depth inquiry into the U.S. and international human rights systems allows for identification of multiple factors at play in both the framing and outcome of any given language rights claim. A list of these factors includes: (1) the level of language ability of the claimant (e.g., monolingual, bilingual); (2) the public or private nature of the context in which the language right is asserted; (3) the importance of the particular subject of communication (e.g., political participation, housing subsidies, criminal

268. Juridical Condition and Rights, supra note 183, ๆ 134.

269. Early on, Piatt suggested a doctrinal framework for language rights. See Piatt, supra note 5, at 902-06. While very skeletal, it included elements of the framework suggested below. Little work has followed to develop his framework further or to suggest an alternative. 
charges) and whether that subject is characterized as a right or benefit; (4) whether affirmative government support is sought or whether a negative right to non-intervention is sought; (5) the status of the involved individuals as immigrants or members of long-standing national minorities; (6) the immigration or citizenship status of the right seekers; (7) the size and degree of concentration of a particular language group; (8) the numerical majority or minority status of a particular language in a country or region; (9) the status of a particular language as relating to a politically powerful or a marginalized community; (10) the indigenous or non-indigenous character of a particular language; and (11) whether the right is asserted as a group right of a particular language community or as an individual right. While this list is lengthy, it is undoubtedly still not fully inclusive.

In fact, the list of influential factors is so long as to be relatively useless in developing a framework for addressing language rights claims going forward. However, exploration of the treatment of language rights claims in the U.S. and internationally, across the broad range of potential settings, makes apparent which of the factors are most salient. A careful look at the case law and norms found in the U.S. legal system and in international human rights law reveal that the most important determinants regarding recognition of language rights are: (1) the rights claimant's monolingual or bilingual language fluency in the minority and majority languages; (2) the negative or affirmative nature of the language right sought; and (3) the private, public or quasi-public setting in which the right is sought to be exercised. While they are largely hidden at present, these factors drive the results without regard to the non-discrimination or cultural identity approach in use.

Contemplation of a series of comparisons of the impact of these three factors on language rights in various settings in the U.S. and international human rights law systems demonstrates their salience. However, two caveats are in order before the comparisons are explored.

First, the comparisons reference existing treatment of language rights claims. They are not intended to demonstrate successful use of the factors for logical and fair resolution of language rights claims but rather just the influence of the three factors. In fact, the comparisons often show the problematic responses that the law provides to language rights claims where, as is currently the case, the relevance of the three salient factors is unrecognized and a doctrinal framework is lacking.

Second, in considering the comparisons, each factor sets out a range of possibilities rather than a binary option. The public/private distinction includes the clearly private sector and the purely governmental public sector. However, it also includes quasi-public settings that are not governmental but act as semi-public spaces, such as the workplace, private schools, and shopping malls. Similarly, the language fluency factor includes a spectrum. Many individuals will be neither clearly monolingual nor bilingual, because 
language capability involves many stages of relative fluency. Even the distinction regarding negative/affirmative claims on the government requires consideration of a range of possibilities, from non-interference to affirmative government-funded support for language, to indirect government intervention such as by making the courts available for language claims involving private actors.

The first comparison looks at claims of a right to interact with government in one's own language. This comparison demonstrates the centrality of the monolingual/bilingual factor. The claims in this area initially handled under international human rights law involved individuals who were bilingual in the dominant majority language used in government as well as in their native minority language. In each of these cases, international human rights bodies denied the language right sought. In Guesdon v. France, the U.N. Human Rights Committee found no right of a bilingual English/French speaker to participate in his criminal trial in English. ${ }^{270}$ And, in a series of cases decided by the European Commission on Human Rights between 1960 and the 1980s, the Commission held that the European Convention on Human Rights did not include a right of bilingual persons to use a minority language in administrative affairs or civil proceedings. ${ }^{271}$ In contrast, in the United States, monolingual minority language speakers have raised most if not all of the claims of a right to interact with government in one's own language. After initial resistance, the U.S. legal system has steadily moved towards recognition of the right of monolingual minority language speakers to interact with government in their language. ${ }^{272}$ For example, the Civil Rights Act has been seen to require language services to non-English speakers seeking to access government programs. ${ }^{273}$ In more recent years, the U.N. Human Rights Committee has also begun to see situations involving monolingual minority language speakers seeking to interact in their language with government. As with the United States, the U.N. Human Rights Committee has now suggested that monolingual minority language speakers enjoy a right to interact with government in their own languages. ${ }^{274}$ The relevance of the monolingual/ bilingual distinction thus becomes apparent, although it has never been explicitly mentioned in the United States or by international human rights bodies.

270. Guesdon, supra note 215.

271. See DE VARENNES, supra note 6, at 45 (listing cases).

272. See supra notes 33, 39 and accompanying text.

273. Alexander v. Sandoval, 532 U.S. 275 (2001) (assuming violation of Title VI of the Civil Rights Act, although no private cause of action, where federally-funded state agency refused to provide driver's license examinations in languages other than English); Exec. Order No. 13,166, supra note 39 (interpreting Title VI of the Civil Rights Act to require the provision of language services to ensure access to federally-funded programs without discrimination on the basis of national origin).

274. See Latvia Concluding Observations, supra note 133, I 19 (expressing concern that official Latvian language policy negatively impacts non-Latvian speakers attempting to access public institutions). 
The second comparison involves the handling of workplace language rights claims. This comparison also highlights the relevance of the language fluency factor but brings in the affirmative/negative right distinction as well.

In general, the U.S. legal system and international human rights law recognize negative rights precluding government intervention regarding languages to be spoken in the workplace. In the United States, the government has not attempted to dictate language use in the private workplace, which is a quasi-public space. The government has apparently assumed a negative right. At the international level, the U.N. Human Rights Committee has found possible language rights violations where government language policies dictate workplace language use. For example, the Committee disapproved of an Estonian government language policy that in practical effect required majority Estonian language fluency for employment even in the private sector. ${ }^{275}$ In the public workplace as well, at least some determinations under U.S. and international human rights law find a negative right prohibiting the government from dictating language use by requiring bilingual government employees to use only the majority language. ${ }^{276}$ Thus, negative rights in the workplace have been granted without regard to fluency or even great regard to the public/private nature of the workplace.

On the other hand, recognition of affirmative language rights in the workplace has hinged on the fluency factor. To date, international human rights bodies have not addressed this scenario. U.S. law is instructive, however. In the United States, limited affirmative language rights have been granted in the private workplace but these rights are generally applied only to monolingual minority language speakers. Thus, the leading workplace language rights cases of Garcia v. Gloor and Garcia v. Spun Steak presumed a right of monolingual minority language speakers to protection against discrimination based on their lack of English fluency. ${ }^{277}$ Monolingual minority speakers may claim some level of affirmative government action to ensure this right is guaranteed, in the form of access to the courts for redress and even government prosecution of violations of this rule. ${ }^{278}$ However, the result is different for bilingual speakers in the private workplace seeking an affirmative right to protection by the government of a right to speak a minority language. Bilingual speakers with competence in a minority language and English do not generally receive affirmative government inter-

275. U.N. Human Rights Comm., Concluding Observations: Estonia, I 16, U.N. Doc. CCPA/CO/ 77/EST (Apr. 15, 2003) [hereinafter Estonia Concluding Observations].

276. Maldonado v. City of Altus, 433 F.3d 1294 (10th Cir. 2006); Ruiz v. Hull, 957 P.2d 984 (Ariz. 1998); Diergaardt, supra note 219, \ 10.10.

277. Garcia v. Spun Steak Co., 998 F.2d 1480 (9th Cir. 1992); Garcia v. Gloor, 618 F.2d 264 (5th Cir. 1980).

278. See 42 U.S.C. $\$ 2000$ e-5 (providing for EEOC to enforce employment discrimination provisions). 
vention in the United States. ${ }^{279}$ In the workplace, then, the fluency factor has determined which affirmative rights will be granted.

The third comparison looks at the education context. This comparison provides a revealing demonstration of the weight given to the private/public setting spectrum and the negative/affirmative right factor.

Current case law and practices in the United States and under international human rights law leave little doubt that a right exists to private education in one's language without government interference. Meyer v. Nebraska resolved this issue decisively in the United States. ${ }^{280}$ International human rights decisions also affirm this right. ${ }^{281}$

However, the likelihood of recognition of the right to education in one's language shifts when an affirmative right is sought in private schools, which should be viewed as quasi-public spheres. In the United States, arguments have generally not been made for an affirmative language right requiring government funding of minority language education in private schools. Under international human rights law, adjudicating bodies have struggled with claims asserting a right to government-supported instruction in private schools in a minority language. In the Belgian Linguistics Case, the European Court of Human Rights held that the Belgian government could eliminate subsidies to private schools for instruction in languages other than the governmentally-designated language in a school district. ${ }^{282}$ The U.N. Human Rights Committee tentatively reached a different conclusion in a more recent analysis of the education system in Latvia. The Committee suggested that a government refusal to subsidize private instruction in minority languages such as Russian might be impermissible if government subsidies were available for private instruction in the majority Latvian language. ${ }^{283}$ The decisions of the two bodies, which reached different conclusions regarding affirmative government support, were clearly more difficult than those involving only negative rights in the private education realm, highlighting the importance of the affirmative/ negative right distinction in this sphere.

Finally, when the comparison in the education context looks at public education, the relevance of the third factor — monolingual/bilingual fluency - takes on a decisive role in connection with the affirmative/negative right distinction. Both the U.S. legal system and international human rights law recognize some affirmative rights in relation to language and

279. Spun Steak, 998 F.2d 1480; Gloor, 618 F.2d 264; Dimaranan v. EEOC, 775 F.Supp. 338 (C.D. Cal. 1991). Cf. Maldonado, 433 F.3d 1294; Metzler v. Fed. Home Loan Bank of Topeka, 464 F.3d 1164, 1171 n. 2 (10th Cir. 2006); Ruiz, 957 P.2d 984.

280. 262 U.S. $390,396,400-02$ (striking down statute criminalizing the teaching of German in private schools); see also Farrington v. Tokushige, 273 U.S. 284, 298-99 (1927) (striking down statute imposing stringent regulations on private schools teaching foreign languages in Hawaii).

281. The Belgian Linguistics Case, supra note 183, ๆ ๆ 7, 13; Cyprus v. Turkey, 35 Eur. Ct. H.R. 731, 1016-17 (2001).

282. The Belgian Linguistics Case, supra note 183, ๆ 13.

283. Latvia Concluding Observations, supra note 133, ๆ 19. 
public schools. The systems differ, though, in identifying who enjoys those affirmative rights. In the United States, in public schools, affirmative language rights are granted at some level but only to monolingual minority language speakers. The Supreme Court recognized in Lau v. Nichols a right to meaningful public school education for students who are monolingual in languages other than English, including through public funding of special programs for non-English speakers. ${ }^{284}$ However, the U.S. courts have resisted recognition of a general affirmative right to instruction in a student's minority language at the government's expense in public schools. ${ }^{285}$ This restriction can be seen as a refusal to grant an affirmative right in public schools to bilingual speakers of English and another language or those who wish to obtain bilingualism. On the other hand, international human rights law generally recognizes a right to public education in one's language, even if not especially, for students who speak both a minority language and the majority language. ${ }^{286}$ Some practicality considerations of logistics and government expense have been imposed on this right, but the focus on promoting culture makes education in minority languages an emphatic goal. The decisions regarding language rights in schools are thus revealed to hinge on the public setting and affirmative rights factors, in interaction with the fluency factor, even where none of these factors are explicit in either the U.S. or the international human rights law systems.

The final comparison looks at private and quasi-public settings beyond the workplace or schools. This comparison highlights the importance of the public/semi-public/private nature of the setting as it relates to the affirmative/negative rights distinction. Both international human rights law and the U.S. legal system have established negative rights to language use in non-public sectors. Thus, for example, the decision of the U.N. Human Rights Committee in Ballantyne recognized the right to use one's own language in advertising in the commercial sphere. ${ }^{287}$ And U.S. courts have recognized the negative right of minority language speakers to be free from government regulation of language in advertising, bookkeeping, and ac-

284. 414 U.S. 563 (1974).

285. See, e.g., Horne v. Flores, 129 S. Ct. 2579 (2009) (finding that laws requiring meaningful education for language minorities do not require education in minority language); Guadalupe Org., Inc. v. Tempe Elementary Sch. Dist. No. 3, 587 F.2d 1022 (9th Cir. 1978) (finding no right to bilingual and bicultural education).

286. U.N. Declaration on Minority Rights, supra note 41, art. 4(3) (requiring instruction in minority language or teaching of minority language where possible); European Charter for Regional or Minority Languages, supra note 61, art. 8; European Framework Convention, supra note 60, art. 14(2); see also Latvia Concluding Observations, supra note 133, ๆ 19 (expressing concern about requiring rapid transition to Latvian as language of instruction including for language minorities); U.N. Comm. on the Rights of the Child, Concluding Observations of the Committee on the Rights of the Child: Morocco, I 14, U.N. Doc. CRC/C/15/Add.60 (Oct. 30, 1996) (expressing concern that the Moroccan state had not taken measures to "provide school education in all the existing languages and dialects").

287. Ballantyne, supra note 68 . 
counting. ${ }^{288}$ On the other hand, neither U.S. law nor international human rights law has established an affirmative right to government action to promote particular language use in the private sector. Once again, the public/ private setting and the affirmative/negative right factors have been hidden but have nonetheless held sway.

\section{B. A Proposed Doctrinal Framework Based on the Most Salient Factors}

The three principal factors identified appear to be the most influential in determining the contours of language rights in the current operation of the U.S. and international human rights legal systems. As such, they can and should be harnessed to establish a consistent doctrinal framework for determining which legal rights to language should be recognized.

The way in which the factors are developed into a framework for determining legal rights depends on the broader conception of language rights in view. Differing frameworks are possible, and each framework configuration could lead to an analysis that would recognize a different set of language rights, all in function of the underlying legal theory or approach driving the framework. This reality provides all the more reason to develop a framework that gives structure to consideration of the three factors. The factors already play a large but mostly invisible and disorganized role in dictating the law's reaction to assertions of language rights. By making the factors and their interaction an explicit focus of analysis, it will be easier to implement any particular language rights theory or approach. Conversely, it will be easier to detect failings of particular conceptions once they can be operationalized through a doctrinal framework.

This Article has presented the case that the U.S. legal system could best handle language rights by incorporating culture-based concerns into its non-discrimination approach and that international human rights law could improve its culture-based approach by incorporating more stringent equal protection standards. While the combined approaches do not lead to an overarching theoretical construct, they provide an adequate normative base for building a framework. The doctrinal framework proposed below, then, seeks to implement a comprehensive approach to language rights that emphasizes non-discrimination as well as the value of diversity and cultural identity based on language. The framework also seeks to acknowledge that even this comprehensive approach assumes some outer boundaries to rights, in line with the principles of equal protection and cultural identity, based on the cost to government and the effects on others of broad minority language rights. While it is initial and tentative, the framework could and should apply across legal regimes, including in the United States and internationally.

288. Yu Cong Eng v. Trinidad, 271 U.S. 500, 528 (1926); Asian Amer. Bus. Grp. v. City of Pomona, 716 F. Supp. 1328 (C.D. Cal. 1989). 
To clarify, the framework based on the three factors does not propose a three-step analysis or a direct push/pull relationship between the three factors (e.g., the more public the arena, the greater affirmative government action required). Instead, the three factors should be seen as three sliding scales that intersect with one another at different points depending on the nature of a given language rights claim. Working through the interactions of the three factors, moving from the private sphere to the quasi-public sphere and finally to the public sphere, the proposed doctrinal framework would handle rights claims in the following way.

\section{Language Rights in the Private Sphere}

Beginning with the easiest interaction of the three factors, in the private sphere, individuals would have the right to use the language of their choice in private without any intervention from the government and, conversely, would have no claim on the government to affirmative assistance for purely private use of language. This result for private use of minority language would hold true whether the minority language speakers were also fluent in the majority language or not. While it seems so obvious as to be uninteresting to assert that the government should not interfere in private decisions regarding language use, there is actually a long history of government intervention into language use in the private sphere in the United States and around the world, and that interference has not completely faded away. ${ }^{289}$ To cite just one troubling example in the United States, some judges considering child welfare and custody cases have ordered parents to learn English and speak it at home or risk losing their children. ${ }^{290}$ The right to be free from discrimination and to enjoy and develop one's culture without interference would both be protected under a scheme that ensures negative language rights in the private sphere.

\section{Language Rights in the Quasi-Public Sphere}

In the workplace, business settings, and other quasi-public arenas, such as private hospitals or schools, claims to negative rights should be honored so that governmental regulation generally cannot restrict what languages are spoken in these arenas. These negative rights should be enjoyed by monolingual minority language speakers and by individuals fluent in both minority and majority languages.

However, claims for some basic affirmative language rights in the quasipublic realm should be honored as well for both monolingual minority lan-

289. See, e.g., BARON, supra note 7 , at 111, 147 (describing laws passed after World War I that prohibited the use of languages other than English in telephone and other conversations); Concluding Observations Estonia, supra note 275.

290. See Judge Orders Parents to Learn English, FoxNews.Com, http://www.foxnews.com/story/0, 2933,148850,00.html (last visited Nov. 17, 2010) (Tennessee judge ordered a mother facing allegations of child neglect to learn English). 
guage speakers and bilingual speakers of majority and minority languages. As is currently the case in the United States, non-majority language speakers should be seen as the victims of unlawful discrimination when employers or other private actors require majority language fluency for jobs or activities that do not require them. An understanding of discrimination informed by a cultural analysis should be implemented to recognize that rules requiring use of a majority language in the quasi-public sphere negatively impact bilingual speakers as well. Whether they speak the majority language or not, speakers of minority languages suffer harm when employers, businesses, or private schools impose rules that require use of the majority language. ${ }^{291}$

Individuals should generally be permitted to speak with one another in the language of mutual choice as they go to school, work, or market given the cultural impact of language restrictions and their likely discriminatory undertones. However, the government may need to act affirmatively to preserve that choice. An intermediate level of government intervention is necessary, not to dictate the language to be used in the quasi-public sphere, but to ensure that employers or other private actors do not implement such dictates except where actually necessary for communication. In the cases of both monolingual minority speakers and bilingual speakers, an affirmative claim to government intervention in the quasi-public sector is proper in the sense that courts and governmental agencies charged with addressing discrimination should accept claims of improper imposition of the majority language and provide relief as appropriate. In this way, the non-discrimination and cultural rights of individuals speaking a minority language are protected at little cost to the government and in a realm where the government and the public have little interest in mandating majority language usage among consensual users of a non-majority language.

\section{Language Rights in the Public Governmental Sphere}

In the true public governmental sphere, as well, minority language speakers should enjoy negative language rights. For example, governments should not exclude bilingual individuals from governmental interactions, such as jury service, simply because they speak a minority language as well as the majority language. In addition, minority language speakers should be allowed to use their native language in the public realm without intervention by the government, whether or not they also speak the majority language. For example, legislators, presidents, governors, and mayors may wish to address one another or their constituents in a minority language. Parents and affected residents may wish to make statements in a minority

291. It is not difficult to find examples of harmful language use rules in the quasi-public sphere. See, e.g., Hernandez v. Erlenbusch, 368 F. Supp. 752 (D. Or. 1973) (discussing tavern that prohibited use of foreign languages at the bar); Ron Sylvester, School Prevails in English-Only Lawsuit, THE Wichita Eagle, Aug. 16, 2008, at A1 (private school prohibited the use of Spanish among students). 
language at school board or town hall meetings. The government should not interfere in these contexts. ${ }^{292}$ Use of a minority language in the public sphere often serves an important purpose in exercising and affirming cultural identity, while recognizing a negative right in this sphere does not create an undue burden on the government or implicate discrimination concerns for other language speakers.

Individuals who speak the majority language as well as a minority language should not, however, generally enjoy a right to affirmative government action to ensure use of the minority language in interactions with the government. Bilingual individuals should not have the right to demand interpretation of their interventions in public debates into the majority language. Nor should bilingual individuals have a positive right to demand government interpretation or other services in the minority language or to file applications or complaints with the government in the minority language. Governments would be permitted to designate a language or languages presumptively to be used by and with the government where a government response is expected. Individuals seeking government services, such as welfare benefits, as well as individuals facing criminal trials or involved in civil proceedings, could be required to use the majority language so long as they are competent in that language as well as their minority language. ${ }^{293}$ While the presumptive operation of a government in a majority language creates an unfavorable distinction in the treatment of native speakers of minority languages, it is justified for individuals who speak the majority language as well as their mother tongue, by increased government efficiency and conservation of resources. Culture-based concerns should generally not outweigh the government's interests in facilitating the dayto-day activities of government. Most daily public sphere activities are not well-suited to the recognition or promotion of minority language and culture. Where cultural identity is at issue, it should be sufficient to allow use of a minority language without restriction but also without affirmative government support.

On the other hand, individuals not fluent in the majority language should be entitled to claim an affirmative right to government assistance in public settings through delivery of services in the minority language or through the provision of interpretation or translation support. A refusal to provide affirmative services to monolingual minority language speakers results in exclusion from government on an unequal basis, which is very

292. This rule generally applies in the United States. See Ruiz v. Hull, 957 P.2d 984 (Ariz. 1998); Patten \& Kymlicka, supra note 9, at 20. But see BARON, supra note 7, at 143 (describing 1919 Nebraska law prohibiting use of languages other than English in public discussions). The same does not hold true internationally. See Podkolziha v. Latvia, 2002-II Eur. Ct. H.R. 443, 453-54, 459-60.

293. In this context, the government must take seriously the fact that language capability falls on a continuum. The government entities involved must make careful assessments as to whether an individual's majority language capabilities allow meaningful interaction with the government in a specific context, such as a criminal trial. 
harmful. Government functions are broad and include not only areas such as the courts and welfare assistance, but also police and emergency health and disaster services. All members of the public must be able to access government and its functions, ${ }^{294}$ and that right should prevail over the cost to governments of providing language services. ${ }^{295}$ A failure to provide access would constitute unjustifiable discrimination under any serious equal protection analysis.

The framework would propose a final layer of analysis for the government public sphere, though, that requires some special consideration. There are some public/government sphere activities that are essential to democratic governance and to the development and expression of individual identities through participation in society. Culture-based concerns are thus heavily at issue along with equal protection concerns. The two most obvious areas are elections and public education. For these, the analysis of the intersection of the public sphere with language ability and demands for affirmative or negative rights should come out slightly differently to grant additional affirmative rights even to multilingual speakers.

As to electoral politics, both monolingual minority speakers and speakers of the majority language should have a full opportunity to participate in the language of their choice and ability. The general framework described above, guaranteeing negative rights to minority language use and requiring affirmative assistance to monolingual minority language speakers, would generally be sufficient in the electoral sphere. Ballots and other materials would need to be translated into minority languages where necessary to ensure participation in elections. For bilingual individuals, the negative right would prohibit government rules limiting the ability of members of language minorities to run for election or dictating language use in campaigns and elections. ${ }^{296}$ Affirmative assistance is generally not necessary, because individuals may discuss politics and campaign in a minority language without government assistance. Candidates and parties will generally have incentives to ensure that information for elections is made

294. Language access must be available to all government services and programs, including, for example, to hospitals that receive government funds.

295. This result would not require translation of all government actions and documents into all languages spoken in a country. It would require some manner of access to government programs and services in the language of a minority language speaker. It is not impossible or even exorbitantly costly for the government to interact with individuals speaking multiple languages. A sliding scale approach can ensure use of the greatest resources, such as translation of documents into multiple minority languages, for interactions on the most important matters with the largest minority language communities. Governments can utilize less costly measures, such as bilingual staff or volunteer interpreters, to interact with smaller language groups where the details of specific documents are not crucial. The government also enjoys efficiencies as a result of improved communication. See generally U.S. Gov'T Accountability Office, Language Access: Selected Agencies Can Improve Services to Limited English Proficient Persons (2010), available at http://www.gao.gov/new.items/d1091.pdf.

296. Some governments currently do establish language rules in the electoral arena. See U.N. Human Rights Comm., Ignatane v. Latvia, U.N. Doc. CCPR/C/72/D/884/1999 (July 31, 2001) (government prohibited candidacy of minority language speaker). 
available in minority languages to those who are interested in receiving it. ${ }^{297}$ Some moderate level of affirmative government action may be necessary, though. For example, the government may need to regulate the media to ensure that mass communication of campaign information is available in minority languages.

However, for education, it will not be enough to guarantee substantial affirmative rights only to monolingual minority language speakers. To provide proper respect for the decision of minority language speakers to learn and develop a minority language for themselves and their children, a demand for affirmative government response in the public education arena should be honored. Along with appropriate majority language instruction for monolingual minority language speakers, schools should provide meaningful minority language programs for all students, whether monolingual in a minority language, bilingual, or monolingual in the majority language. While such a program entails cost to the government, it is the best way to avoid the deprivation of culture-based language rights that takes place when schools assimilate by communicating that a majority language is the only one of value.

\section{CONCLUSION}

In our increasingly globalized world in which people regularly interact with other languages and language communities within and outside of their countries of origin, it is time to strive for greater consolidation of language rights. History has shown that dangerous divisions among language groups usually do not take place in societies where language diversity is respected, but rather where language differences are treated as undesirable. ${ }^{298}$ The development of a comprehensive and consistent set of language rights will avoid such conflicts while ensuring more complete protection of fundamental rights to equal protection and cultural identity. I hope that the necessary changes will come soon enough to allow my eight-year-old son to reach his bilingual and bicultural potential and to enjoy the "thrilling experience of being dual, of taking from one linguistic river and then dipping into the other until the confluence of the two vocabularies connects distant communities." 299

297. See, e.g., Edward Hegstrom, Gore and Bush Employ Splintered Spanish But Hispanics Seem to Applaud the Effort, Seattle Post-Intelligencer, Sept. 27, 1999, http://www.seattlepi.com/national/span 27.shtml.

298. BARON, supra note 7, at 180; De VARENNEs, supra note 6, at 275; Kymlicka, The New Debate, supra note 241, at 47-48; Mälksoo, supra note 6, at 439.

299. Ariel Dorfman, If Only We All Spoke Two Languages, in Everything's an Argument with READINGs 704-05 (3d ed. 2004). 